\title{
PERSPEKTIF SEMIOTIK TENTANG REPRESENTASI BUDAYA FEODAL DALAM IKLAN A MILD VERSI "TANYA KENAPA" DENGAN TEMA "BELUM TUA BELUM BOLEH BICARA"
}

\author{
Andjrah Hamzah Irawan \\ Jurusan Desain Produk Industri, Program Studi Desain Komunikasi Visual \\ Fakultas Teknik Sipil dan Perencanaan, Institut Teknologi Sepuluh \\ Nopember Surabaya
}

\begin{abstract}
Abstraksi
Penelitian yang mengangkat iklan sebagai objek penelitian, menjadi hal yang menarik bagi peneliti. Karena iklan merupakan media yang memilki tanda visual yang berhubungan dengan tanda yang ada di masyarakat. Tiap tanda-tanda memiliki relasi/ asosiasi, sehingga menghasilkan makna yang tergantung dari sudut pandang pembaca iklan. Peneliti mengambil iklan sebagai objek penelitian yaitu Iklan A Mild tema " Belum Tua Belum Boleh Bicara", iklan tersebut menurut peneliti memiliki nilai-nilai feodal yang terdapat dalam tanda - tanda seperti pada komposisi, gesture, warna, aksentuasi, tagline, dll.

Studi mengenai tanda atau Semiotika ini, peneliti menggunakan terori dari C.S. Pierce tentang Ikon, Indeks, dan Simbol. Budaya Feodal dalam iklan ini bertujuan untuk mengkritik kondisi dimasyarakat, fenomena yang ada di masyarakat bahwa budaya Feodal masih mempengaruhi seseorang dalam pergaulan, berpikir, berkomunikasi, berpendapat, birokrasi, dll. Sehingga paham seperti ini dapat memperhambat perkembangan masyarakat itu sendiri. Selain itu, budaya Feodal bertentangan dengan prinsip-prinsip Demokrasi yang memberikan kebebasan untuk melakukan hak masingmasing.

Kritikan pada masyarakat melalui tanda-tanda dalam iklan A Mild ini, melalui tampilan burung pelikan tua dan muda yang bertolak belakang, tinggi- rendah, jauh-dekat, warna, ekpresi pelikan. Maka representasi iklan tersebut mengarah pada tanda yang berhubungan dengan relasi sosial.
\end{abstract}

Kata Kunci: Representasi Semiotika, Feodal, Iklan A Mild. 


\section{Pendahuluan}

Dunia periklanan yang berkembang pesat saat ini menjadikan kondisi masyarakat yang semakin konsumtif. Iklan cetak tersebar di berbagai macam media, dengan menampilkan berbagai macam penawaran yang menarik dengan menunjukkan keunggulan, manfaat, harga yang terjangkau, image, dll dari produk-produk yang di iklankan.

Periklanan sebagai alat promosi dengan proses komunikasi yang kuat dan dijadikan sebagai alat pemasaran untuk membantu penjualan barang, memberikan layanan, serta gagasan atau ide-ide melalui saluran tertentu dalam bentuk informasi yang persuasif. Iklan termasuk dalam kajian industri media dan budaya. Sehingga, iklan menjadi salah satu bagian yang tidak bisa terelakkan oleh masyarakat. ${ }^{1}$

Periklanan membentuk pikiran konsumen untuk bisa terpengaruh oleh iklan. Iklan bisa disebut sebagai salah satu industri budaya, yang mana industri budaya adalah sesuatu yang memiliki fungsi utama produksi atau distribusi seni, hiburan atau informasi. Pernyataan iklan dalam buku How To Do Media and Cultural Studies menunjukkan bahwa iklan merupakan kumpulan kode - kode dan tanda-tanda yang mengandung nilai sosial, budaya dan ideologi didalamnya.

Munculnya berbagai macam iklan cetak produsen berusaha untuk mengambil hati tiap konsumen yang melihat. Tetapi berbeda kondisi dengan iklan untuk produk rokok, iklan rokok telah memiliki peraturan sendiri untuk berpromosi di media cetak maupun elektronik, yaitu tercantum pada PERATURAN PEMERINTAH REPUBLIK INDONESIA NOMOR 81 TAHUN 1999 TENTANG PENGAMANAN ROKOK BAGI KESEHATAN.

Sehingga iklan rokok menjadi sebuah iklan kreatif tanpa menunjukkan produk yang di jual, yang dijual dalam iklannya adalah sebuah image/ citra, bayangan atau kritikan. Kesan yang timbul adalah iklan rokok cenderung bersifat konotatif, seperti pada iklan rokok A Mild tema "Belum Tua Belum Boleh Bicara". Iklan yang bertema serial ini cenderung melakukan sebuah kritik sosial pada budaya Feodal di masyarakat, ini adalah salah satu strategi untuk melakukan pendekatan pada masyarakat.

Iklan dibahas dalam penelitian ini, dikarenakan iklan mempunyai sebuah fenomena budaya Feodal yang menarik untuk diangkat, banyak nilai dan makna yang perlu diangkat atau direpresentasikan secara mendalam, ada apa sebenarnya dibalik iklan, unsur - unsur ideologi apa yang terkandung didalamnya, sehingga iklan mempunyai persepsi dan interpretasi yang berbeda-

\footnotetext{
${ }^{1}$ Rendra Widyatama, Pengantar Periklanan, (Yogyakarta:Pustaka Book Publisher, 2007), hal. 12
} 
beda. Karena didalam iklan mengandung banyak fenomena sosial yang dituangkan dalam bentuk tanda-tanda visual. ${ }^{2}$

\section{Metodologi Penelitian}

\section{Objek Penelitian}

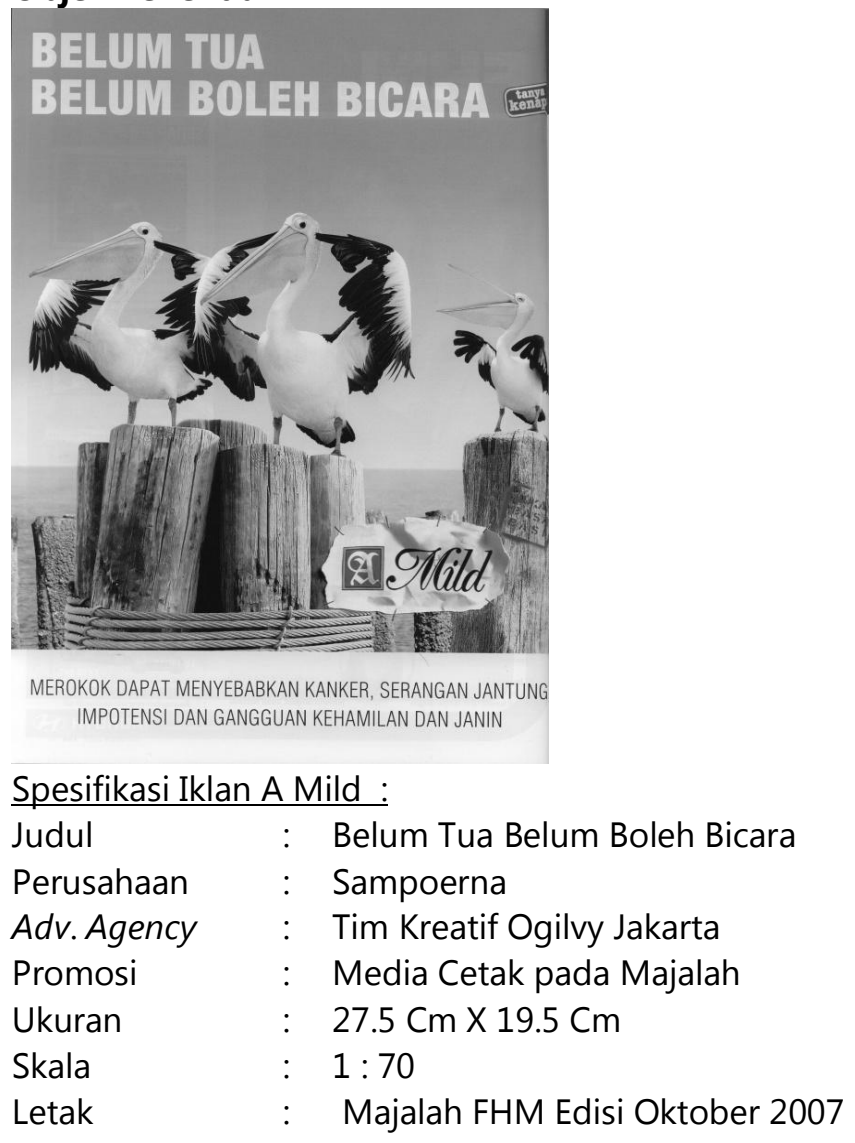

Penelitian yang mengambil objek penelitian iklan diatas, yang merupakan sebuah iklan yang memberikan kritikan pada masyarakat. Iklan yang dibuat pada bulan Oktober tahun 2007 yang diterbitkan di majalah FHM. Setiap pembuatan iklan A Mild pasti memiliki alasan dibalik iklan. Iklan versi tanya kenapa selalu memberikan pembelaan kepada masyarakat umum mengenai kondisi masyarakat saat ini. Fenomena - fenomena dimasyarakat diangkat dan

2 Thomas, Linda, Wareing, dan Shan, Bahasa, Masyarakat, \& Kekuasaan. (Yogyakarta:Pustaka Pelajar, 2007), hal. 23 
dijadikan sebuah tema yang unik dan mengkritik. Oleh karena itu peneliti ingin mengungkap budaya Feodal yang ada dalam iklan tersebut.

\section{Pendekatan Penelitian}

Dalam penelitian kualitatif ini, peneliti harus mengesplorasi makna makna dalam iklan. Iklan A Mild sebagai objek penelitian akan diteliti dengan menggunakan teori Semiotik dari C.S. Pierce. Kajian visual image ini fokus meneliti pada makna denotasi, konotasi dan ideologi dengan relasi-relasi antara iklan dengan masyarakat. Untuk tata cara penelitian, penelitian ini diawali dengan melakukan sebuah dokumentasi pada objek penelitian yaitu iklan A Mild, kemudian melakukan pengamatan secara cermat pada objek penelitian.

Iklan yang sudah diamati oleh peneliti ini kemudian dianalisa sebagai objek penelitian dengan menggunakan teori semiotika. Didalam iklan terdapat ikon, simbol dan indeks, yang mana bisa berupa komposisi, warna, teks, foto, latarbelakang, dll. Aplikasi penerapan penelitian terdapat pada ikon, indeks dan simbol. Ikon untuk melihat pada sisi latar belakang, warna, ekspresi, komposisi, dan teknik lainnya dalam iklan. Pada simbol digunakan untuk melihat makna pada tanda dalam iklan dengan melalui tanda yang ada kesepakatan dalam masyarakat. Indeks untuk melakukan relasi iklan dengan tanda - tanda yang ada. Sedangkan pada bagian argumen digunakan untuk melihat makna ideologi apa dibalik iklan ini. ${ }^{3}$

Pada bagian Metodologi, penelitian yang membahas tentang bagaimana iklan dimaknai sebagai teks dengan kesepakatan makna masyarakat. Konotasi yang digali menjadi sebuah nilai tersendiri bagi peneliti, penelitian yang dilakukan dengan cara aktifitas masyarakat yang bersangkutan dengan efek media. Analisa yang dilakukan adalah dengan melihat level realitas dan ideologi yang ada didalam tanda iklan. Pendekatan pada aspek sosial mengenai masalah sehari-hari yang menimbulkan ketidakseimbanganlah yang dikritik dalam iklan A Mild ini. Iklan yang memberikan gambaran visual yang menarik sehingga membantu untuk mempersuasi konsumen.

\section{Sasaran Penelitian}

Dalam bagian sasaran penelitian ini, peneliti memberikan penjelasan mengenai kapan, fenomena, situasi dan kondisi iklan ini dibuat. Iklan ini dibuat pada pertengahan tahun 2007 sekitar bulan September. Iklan dibuat oleh sebuah perusahaan iklan Ogilvy di Jakarta dengan ide-ide menarik, ide yang berbeda dengan iklan rokok lainnya. Tim kretif iklan tersebut melihat

\footnotetext{
3 Jane Stokes, How To Do Media and Cultural Studies. Panduan untuk Melaksanakan Penelitian dalam Kajian Media dan Budaya., (Yogyakarta: Bentang, 2007), hal. 56
} 
masyarakat dengan berbagai sudut pandang, seperti pada budaya, fenomena sosial, situasi dan kondisi masyarakat. Tim kreatif melihat adanya sebuah fenomena sosial pada masyarakat, fenomena yang mengenai ketidakseimbangan antara tua dan muda, kebiasaan yang dilakukan oleh orang yang lebih tua pada anak muda, menganggap anak muda tidak berhak, tidak mampu, tidak dipercaya, tidak boleh untuk melakukan apapun didepan orang yang lebih tua. Sehingga sulit menggabungkan kelas anak muda dengan kelas orang tua, dalam satu kondisi dimasyarakat terlihat bahwa orang yang lebih tua lebih ingin dihargai, dihormati, mengganggap dirinya lebih mampu. Kelas orang tua merasa dirinya lebih tahu, lebih mengerti, daripada kelas anak muda. Fenomena tersebut menjadi sebuah ide yang menarik untuk dibuat sebagai iklan. Dengan demikian, masyarakat dalam fenomenanya masih memiliki budaya melihat hirarki sosial dan membatasi hak orang lain. Fenomena budaya feodal masih melekat dimasyarakat, padahal negara kita berpaham Demokrasi yang memberikan kebebasan hak dan menghargai perbedaan. Paham ideologi Demokrasi dengan budaya feodal merupakan paham yang bertolak belakang.

Peneliti melihat fenomena dalam masyarakat seperti itu, peneliti akan melihat budaya feodal yang masih berjalan dalam masa Demokrasi saat ini. Apakah iklan ini memberikan kritik pada masyarakat dengan melalui tandatanda dalam iklan ini.

\section{Teknik Pengumpulan Data}

Pada penelitian ini, peneliti menganalisa iklan dalam kajian semiotika. Iklan cetak Rokok Sampoerna A Mild yang hanya berupa gambar / visual tanpa ada audio. Iklan rokok yang di cetak di majalah atau media massa, sehingga teknik pengumpulan data yang akan dilakukan dalam penelitian ini adalah dengan cara sebagai berikut:

1. Dokumentasi

Dokumentasi dilakukan dengan mengambil Iklan dari majalah, yang terpenting gambar iklan tersebut bisa terlihat jelas dan bagus. Hal ini dilakukan untuk mendapatkan data awal. Data awal ini sangat penting untuk memulai penelitian hingga penelitian berakhir. Kita bisa melihat warna, bentuk, proporsi, ukuran, dimensi dan estetika dari iklan tersebut.

2. Kepustakaan / Literatur

Teknik pengumpulan data yang digunakan adalah studi pustaka, yaitu mengolah data dari buku-buku, jurnal ilmiah, majalah, dan situs internet yang berhubungan dengan topik penulisan. 


\section{Teknik Analisa Data}

Teknik analisa data yang digunakan oleh peneliti adalah analisa semiotika C.S. Pierce yang membahas mengenai tanda-tanda dalam iklan yang akan di maknai dengan tanda yang ada dimasyarakat. Tanda dimasyarakat yang dijadikan menjadi satu dalam sebuah budaya, yang mana iklan A Mild ini mengangkat kajian budaya dalam masyarakat.

Jika kita amati iklan yang terlihat ini, menonjolkan gambar burung pelikan dan kayu pancang di tepi laut. Dalam analisa semiotik kita harus membagi iklan tersebut menjadi beberapa bagian. Iklan mempunyai tanda yang mana tanda tersebut mempunyai relasi dengan budaya masyarakat, untuk analisa digunakan teori dari C. S. Pierce yang membagi tanda menjadi 3 (tiga) yaitu, ikon, indeks dan simbol. Untuk pengertian dari ikon, indeks dan simbol telah dijelaskan pada Bab Pustaka.

Didalam iklan yang terlihat banyak tanda-tanda yang sudah mengalami konvensi sehingga menjadi sebuah kesepakatan antara tanda dengan objek. Didalam iklan yang terlihat akan dikaji secara mendalam tentang tanda.

Jika diteliti, iklan mengandung tanda. Tanda dalam iklan A Mild tersebut berdasarkan objeknya, yaitu:

1. Ikon

Contoh dalam iklan : foto burung, foto pantai

2. Indeks

Contoh dalam iklan : Sayap yang lebar menandakan burung tersebut sudah tua/ dewasa

3. Simbol

Contoh dalam iklan : teks didalam iklan yang tersusun dari beberapa kata

Kemudian Tanda dalam iklan diteliti berdasarkan interpretan yang terbagi menjadi beberapa kelas tanda, yaitu:

Qualisign, yakni kualitas yang dimiliki tanda.

Contoh: mulut burung pelikan kecil yang terbuka lebar menandakan burung tersebut berbicara dengan keras.

Iconic Sinsign, yakni tanda yang memperlihatkan kemiripan.

Contoh : foto burung pelikan, foto pantai.

Rhematic Indexical Sinsign, yakni tanda berdasarkan pengalaman langsung, yang secara langsung menarik perhatian karena kehadirannya disebabkan oleh sesuatu.

Contoh : kayu yang diikat dengan tali, menandakan kayu tersebut sudah rapuh, tidak kuat menyangga sendiri. 
Dicent Sinsign, yakni tanda yang memberikan informasi tentang sesuatu. Contoh : Burung pelikan yang menutup telinganya, menginformasikan bahwa mereka tidak mau mendengarkan suara.

Iconic Legisign, yakni tanda yang menginformasikan norma atau hukum. Contoh : Kata-kata "Belum Tua Belum Boleh Bicara".

Rhematic Indexical Legisign, yakni tanda yang mengacu kepada objek tertentu.

Contoh : Lirikan mata kedua burung pelikan dewasa kepada burung pelikan kecil.

Dicent Indexical Legisign, yakni tanda yang bermakna informasi dan menunjuk subjek informasi.

Contoh : Tali yang mengikat tiang kayu menandakan tiang-tiang kayu tersebut sulit untuk dirobohkan.

Rhematic Symbol atau Symbol Rheme, yakni tanda yang dihubungkan dengan objeknya melalui asosiasi ide umum.

Contoh : Kita melihat gambar burung pelikan, kita pasti mengatakan hewan itu dengan sebutan burung pelikan, karena ada asosiasi antara gambar dengan hewan dinamakan burung pelikan.

Dicent Symbol atau Proporsition (Proposisi), yakni tanda yang langsung menghubungkan dengan objek melalui asosiasi dalam otak.

Contoh : kata-kata "belum boleh bicara"

Argument, yakni tanda yang merupakan iferens seseorang terhadap sesuatu berdasarkan alasan tertentu.

Contoh : jika kita melihat burung pelikan dan mengatakan burung pelikan itu tua / dewasa.

Mengungkap makna pada tanda dalam iklan yang merupakan kajian visual image yang mendeskripsikan makna yang ada dibalik iklan tersebut. ${ }^{4}$ Peneliti ingin melihat hubungan makna tanda dalam iklan dengan menggunakan paradigma visual yang melihat pada setting, komposisi, hubungan antar objek dan ekspresi. Berdasarkan pengamatan peneliti pada iklan A mild terdapat perbedaan komposisi pada burung pelikan tua dan muda, komposisi yang tidak seimbang atau didominasi oleh burung pelikan tua. Burung pelikan tua lebih ditonjolkan dalam segi komposisi sehingga terlihat lebih besar, lebih close up. Pada komposisi ini terlihat bahwa terdapat perbedaan kelas, strata pada tingkat sosial. Pada iklan ini terlihat strata orang tua lebih tinggi daripada anak muda, tampilan visual iklan terlihat kayu penyangga yang berbeda ukuran, bentuk dan kerutan.

Iklan ini berusaha menggambarkan bahwa orang tua lebih mempunyai kekuatan, pengalaman, dan hubungan yang lebih besar daripada anak muda

\footnotetext{
${ }^{4}$ Frank Jefkins, Periklanan (edk. 3; Jakarta: Penerbit Erlangga, 1997), hal. 37
} 
yang tiang penyangganya kecil. Dominasi orang tua pada iklan terlihat tampak bagi peneliti, hirarki sosial terlihat, budaya feodal yang masih mendominasi sehingga tidak ada keseimbangan dalam bermasyarakat. Analisa ini memberikan gambaran bahwa ada ideologi yang ingin disampaikan iklan pada masyarakat yang mungkin digunakan untuk menyindir masyarakat.

\section{Hasil Dan Analisa Penelitian}

Hasil dan analisa penelitian akan membantu untuk menjawab/ menyelesaikan permasalahan dari penelitian ini. Iklan A Mild yang berjudul "Belum Tua Belum Boleh Bicara" ini, peneliti melakukan analisa secara denotasi dan konotasi dengan menggunakan relasi tanda-tanda yang relevan, sehingga mendukung proses analisa semiotika C.S Pierce. Proses ini akan dibagi terperinci satu persatu, bagian -bagian tersebut adalah :

1. Filosofi burung Pelikan

2. Sejarah Kayu Jati

3. Konsep warna dan kesan dalam iklan

4. Burung Pelikan tua berkumpul

5. Sayap Burung Pelikan tua

6. Burung Pelikan Tua Melirik

7. Paruh Burung Pelikan Tua dan Pelikan Muda

8. Burung Pelikan tua dan muda diatas kayu jati

9. Gesture dan Ekspresi burung Pelikan tua dan muda

10. Latar belakang lautan dan langit

11. Tagline(Tipografi)

\section{Filosofi Burung Pelikan}
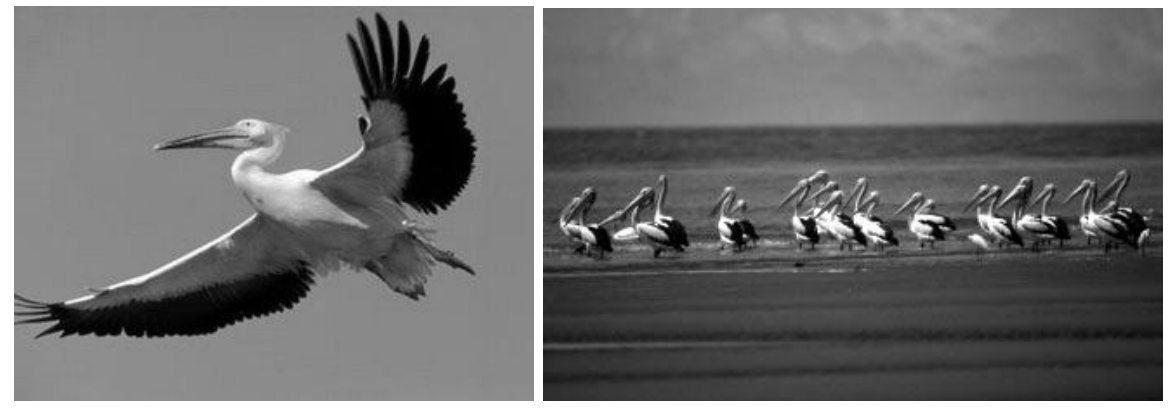

Burung pelikan memiliki aktifitas rutin yang dilakukan, yaitu mencari ikan di pagi hari saat sinar matahari belum terasa panas, lalu berjemur di bawah sinar matahari saat perut sudah terasa kenyang, dan begitu matahari mulai menghilang mereka masuk ke dalam lubang pasir untuk beristirahat. Burung Pelikan bukan termasuk hewan asli Indonesia, tetapi mereka berasal dari 
Australia. Mereka berkunjung ke Indonesia hanya untuk mencari makan, karena negara asalnya sedang turun salju sehingga mereka kekurangan makanan. Saat musim salju selesai, mereka akan kembali lagi ke Australia. Tapi begitu kekurangan makanan lagi, mereka akan berbondong-bondong datang ke Indonesia. Kawanan pelikan tersebut datang ke Indonesia khusus untuk mencari makan dan bukan untuk menetap atau berkembang biak. Saat tubuh sudah gemuk, mereka akan kembali ke negara asalnya. Bahwa kawanan pelikan yang datang ke Papua tidak saja berasal dari Australia, tetapi juga dari benua lain yang mengalami musim salju.

Pelikan merupakan spesies burung sebagai penerbang tangguh. Tidaklah berlebihan jika dikatakan demikian, mengingat kedatangan burung migran ini ke Papua tanpa beristirahat sedikit pun sejak dari Australia. Burung yang selalu terbang dalam jumlah ratusan ini bukanlah tipikal burung laut yang dapat berenang di tengah keganasan ombak laut. Pelikan adalah jenis burung pantai yang dapat berenang hanya di pinggiran pantai. Pelikan tidak mungkin beristirahat dengan mengambang di tengah besarnya ombak laut antara Australia-Papua. Apalagi tidak ada satu pun pulau yang bisa dihampiri. Kawanan pelikan pasti terbang tanpa henti dari Australia ke Papua.

Berbicara soal pelikan saat berada di udara, ada hal lain yang menarik yakni saat menyaksikan kawanan burung ini sedang terbang. Jenis burung yang selalu terbang dalam jumlah yang besar ini, akan membentuk formasi mirip ujung anak panah yang berbentuk ' $\mathrm{V}$ ' saat berada di udara. Tidak seperti jenis burung lain yang biasanya terbang secara bergerombol, tetapi burung pelikan terbang dalam sebuah barisan yang teratur, yang dipimpin oleh burung yang berada di ujung sudut formasi. Secara teratur pula, burung pelikan tersebut akan saling bergantian posisi dengan yang ada di belakangnya, sehingga setiap burung bisa menjadi pemimpin rombongan.

Dikatakan sebagai pemimpin, karena burung yang berada di paling depan menjadi acuan arah dan gerakan oleh burung yang berada di belakangnya, kemana pun arah pemimpin terbang, anggota di belakangnya akan selalu mengikutinya. Saat pemimpin menukik ke arah air, anggotanya pun tanpa dikomando akan mengikutinya. Saat berada di udara, burung ini jarang sekali mengepakkan sayap. Kepakannya yang kuat membuat burung ini sudah dapat melaju beberapa puluh meter hanya dalam satu kepakan. Mereka juga kompak dalam hal ini. Jika pemimpin mengepakkan sayap, dengan kompak anggota yang ada di belakangnya pun akan mengikutinya. 


\section{Sejarah Kayu Jati}

Kayu yang terlihat dalam iklan A Mild tersebut merupakan jenis kayu jati, kayu Jati menyebar luas mulai dari India, Myanmar, Laos, Kamboja, Thailand, Indochina, sampai ke Jawa. Jati tumbuh di hutan-hutan gugur, yang menggugurkan daun di musim kemarau. Jati merupakan jenis tanaman besar yang bisa tumbuh hingga bertahun-tahun dan berbentuk besar dan kokoh, sehingga kayu jati banyak diminati oleh masyarakat, karena harga dan kualitas yang istimewa maka kayu jati tergolong jenis kayu yang dilindungi oleh pemerintah.

Kayu Jati paling banyak tersebar di Asia. Selain di keempat negara asal Jati dan Indonesia, jati dikembangkan sebagai hutan tanaman di Srilangka (sejak 1680), Tiongkok (awal abad ke-19), Bangladesh (1871), Vietnam (awal abad ke20), dan Malaysia (1909). Tegakan Jati sering terlihat seperti hutan sejenis, yaitu hutan yang seakan-akan hanya terdiri dari satu jenis pohon. Kayu Jati merupakan kayu kelas satu karena kekuatan, keawetan dan keindahannya. Secara teknis, kayu jati memiliki kelas kekuatan I dan kelas keawetan I. Kayu ini sangat tahan terhadap serangan rayap. Meskipun keras dan kuat, kayu jati mudah dipotong dan dikerjakan. Oleh karena itu, jati banyak diolah menjadi mebel taman, mebel interior, kerajinan, panel, dan anak tangga yang berkelas. Sekalipun relatif mudah diolah, jati terkenal sangat kuat dan awet, serta tidak mudah berubah bentuk oleh perubahan cuaca. Atas alasan itulah, kayu jati digunakan juga sebagai bahan dok pelabuhan, bantalan rel, jembatan, kapal niaga, dan kapal perang. Di dalam rumah, selain dimanfaatkan sebagai bahan baku furniture, kayu jati digunakan pula dalam struktur bangunan. Rumahrumah tradisional Jawa, seperti rumah joglo Jawa Tengah, menggunakan kayu jati di hampir semua bagiannya: tiang-tiang, rangka atap, hingga ke dindingdinding berukir.

Kayu jati jawa telah dimanfaatkan sejak jaman Kerajaan Majapahit. Jati terutama dipakai untuk membangun rumah dan alat pertanian. Sampai dengan masa Perang Dunia Kedua, orang Jawa pada umumnya hanya mengenal kayu jati sebagai bahan bangunan. Kayu-kayu bukan jati disebut 'kayu tahun'. Artinya, kayu yang keawetannya untuk beberapa tahun saja. Selain itu, jati digunakan dalam membangun kapal-kapal niaga dan kapal-kapal perang. Beberapa daerah yang berdekatan dengan hutan jati di pantai utara Jawa pun pernah menjadi pusat galangan kapal, seperti Tegal, Juwana, Tuban, dan Pasuruan. Namun, galang kapal terbesar dan paling kenal berada di Jepara dan Rembang, sebagaimana dicatat oleh petualang Tomé Pires pada awal abad ke-16. VOC (Vereenigde Oost-Indische Compagnie, Kompeni Hindia Timur Belanda) bahkan sedemikian tertarik pada "emas hijau" ini hingga berkeras mendirikan loji pertama mereka di Pulau Jawa —tepatnya di Jepara— pada 1651. VOC juga 
memperjuangkan izin berdagang jati melalui Semarang, Jepara, dan Surabaya. Ini karena mereka menganggap perdagangan jati akan jauh lebih menguntungkan daripada perdagangan rempah-rempah dunia yang saat itu sedang mencapai puncak keemasannya.

Di pertengahan abad ke-18, VOC telah mampu menebang jati secara lebih modern. Dan, sebagai imbalan bantuan militer mereka kepada Kerajaan Mataram di awal abad ke-19, VOC juga diberikan izin untuk menebang lahan hutan jati yang luas. VOC lantas mewajibkan para pemuka bumiputera untuk menyerahkan kayu jati kepada VOC dalam jumlah tertentu yang besar. Melalui sistem blandong, para pemuka bumiputera ini membebankan penebangan kepada rakyat di sekitar hutan. Sebagai imbalannya, rakyat dibebaskan dari kewajiban pajak lain. Jadi, sistem blandong tersebut merupakan sebentuk kerja paksa.VOC kemudian memboyong pulang gelondongan jati jawa ke Amsterdam dan Rotterdam. Kedua kota pelabuhan terakhir ini pun berkembang menjadi pusat-pusat industri kapal kelas dunia.Di pantai utara Jawa sendiri, galangangalangan kapal Jepara dan Rembang tetap sibuk hingga pertengahan abad ke19. Mereka gulung tikar hanya setelah banyak pengusaha perkapalan keturunan Arab lebih memilih tinggal di Surabaya. Lagipula, saat itu kapal lebih banyak dibuat dari logam dan tidak banyak bergantung pada bahan kayu. ${ }^{5}$

\section{Konsep Warna Dan Kesan Dalam Iklan}

Warna sebagai bagian elemen desain memiliki pesan dan kesan didalamnya. Warna dapat dijadikan sebagai tanda yang mengarah pada satu nilai budaya dan ideologi. Karena warna seperti halnya simbol yang mempunyai kesepakatan-kesepakatan dalam budaya dan masyarakat tertentu. Warna memiliki banyak persepsi dalam pemaknaannya, yaitu makna yang direpresentasi oleh masyarakat. Budaya mempengaruhi dalam pemaknaan sebuah warna, seperti warna putih di negara indonesia dengan negara China mempnyai makna yang berbeda.

Iklan A Mild memiliki warna dan kesan yang natural. Warna dibuat oleh tim kreatif untuk melakukan suatu pendekataan pada masyarakat. Pendekatan pada masyarakat salah satunya mengambil simbol-simbol yang sudah disepakati oleh masyarakat. Warna yang natural tidak ingin mengarah pada satu paham atau ideologi, warna natural memberikan sebuah kesan yang realistis dan tidak dibuat-buat. Memang kenyataan dalam masyarakat seperti ini, sehingga pesan yang ingin disampaikan dibuat senyata mungkin. Konsep warna

\footnotetext{
5 Thomas, Linda, Wareing, dan Shan, Bahasa, Masyarakat, \& Kekuasaan, (Yogyakarta: Pustaka Pelajar, 2007), hal.65
} 
bisa melihat segmentasi, ideologi, budaya, nilai-nilai apa yang terkandung didalamnya.

\section{Warna Latar Belakang}

Pada iklan A Mild "Belum Tua Belum Boleh Bicara", warna latar belakang berwarna biru muda gradasi putih kebiruan kebawah, warna biru muda dengan komposisi biru C: 64 ; M: $40 ; Y: 15 ; \mathrm{K}: 0$, untuk warna putih kebiruan $\mathrm{C}: 21 ; \mathrm{M}: 11 ; \mathrm{Y}: 0 ; \mathrm{K}: 0$. konsep warna biru memberikan kesan yang segar, kepercayaan, konservatif, keamanan, ideologi, kebersihan dan keteraturan. Warna laut abu-abu yang memberikan kesan sederhana, dan sebagai warna netral yang mudah untuk dilihat.
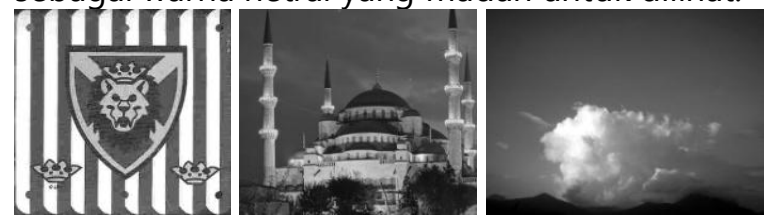

Warna biru juga terlihat pada bendera Blue/Yellow Knight's Kingdom, yang mana referen tanda menunjukkan pada konsep kerajaan, bahwa kerajaan selalu melakukan hal yang konservatif, ideologi, keamanan dan kepercayaan untuk memberikan keyakinan pada rakyatnya, bahwa negara / kerajaan tersebut aman dari segala serangan. Konsep untuk meyakinkan rakyatnya dengan cara memberikan simbol-simbol atau warna-warna yang bisa mewakili, salah satunya yaitu warna biru. Tampilan masjid yang mempunyai budaya, aturan, kepercayaan, konservatif, ideologi dan nilai yang terlihat pada unsur warna biru. Warna memang sebuah hal yang abstrak untuk diyakini, karena warna adalah simbol yang disepakati oleh masyarakat tertentu. Warna abu-abu mempunyai arti masa depan dan intelektualitas, warna abu-abu akan diasosiasikan dengan konsep milenium yang berteknologi tinggi untuk masa depan, asosiasi digambarkan dengan kendaraan berikut ini
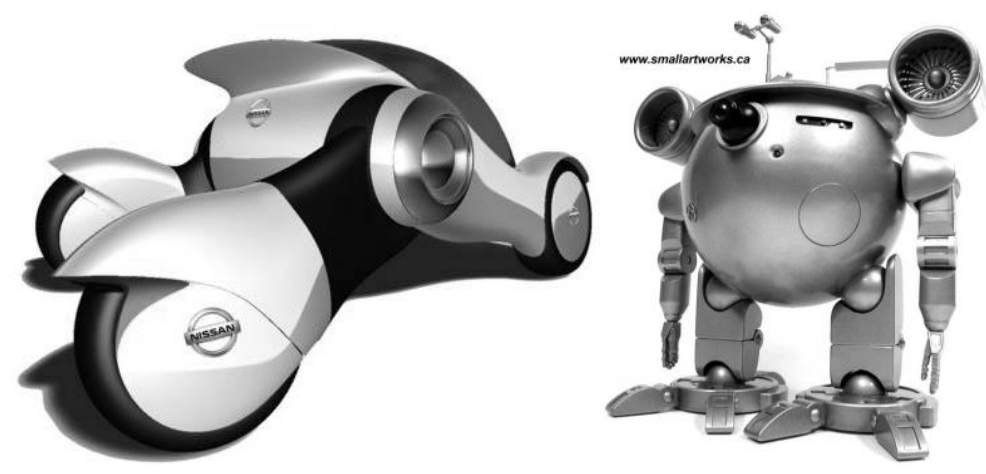

Jurnal Ilmu Komunikasi, Vol. 1, No.1, April 2011

ISSN: 2088-981X 


\section{Warna Burung Pelikan}

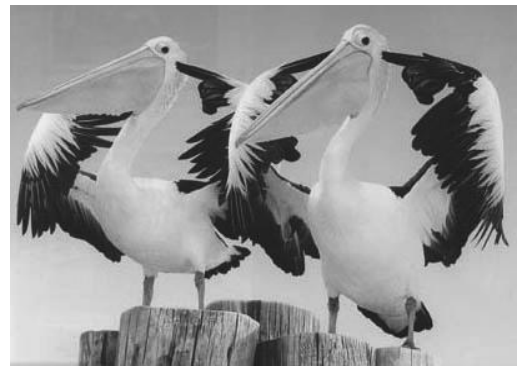

Burung pelikan yang merupakan burung yang berasal dari negara Australia, melakukan perpindahan ke papua dan menetap di sana. Burung pelikan yang mempunyai warna khas putih (bagian badan), hitam (bagian sayap), dan merah muda (bagian paruh), semua warna yang ada dalam burung ini memberikan makna dan simbol tertentu. Dilihat dari komposisi warna burung, warna hitam C: 68 ; M: $71 ; Y: 63 ; \mathrm{K}: 79$, warna putih C: $10 ; \mathrm{M:} 9 ; \mathrm{Y:} 0$; K: 0, warna merah muda pada paruh C: $24 ; \mathrm{M}: 33$; Y: 28 ; K: 0. warna hitam yang melambangkan kekuatan, kebesaran, elegan, dan kekuasaan yang mana ditampilkan dalam tanda berikut:

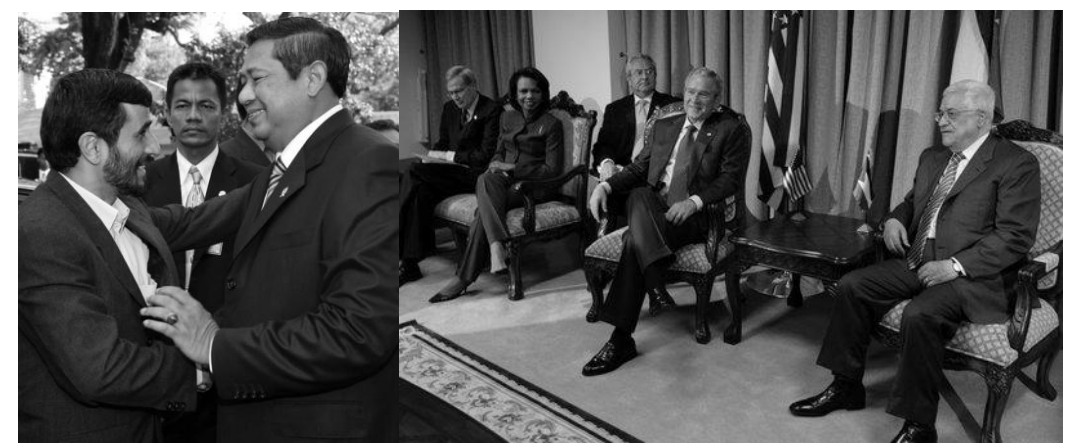

Warna hitam adalah tentang kekuasaan, kekuatan dan elegan, warna hitam pada iklan direlasikan dengan warna hitam yang ada pada tanda - tanda dimasyarakat, seperti relasi pada gambar diatas. Warna hitam yang selalu terlihat bagi para pemimpin negara yang mempunyai kekuasaan dan kekuatan. Warna hitam pada penelitian ini memberikan arti yang lebih cenderung pada kekuasaan bukan pada arti kematian. Putih melambangkan kesucian, dan ketepatan, gambaran pada burung pelikan bahwa burung pelikan merupakan sebuah simbol sesuatu yang pasti dan bersih (netral).

Relasi warna pada sayap dengan warna pada jas penjabat mempunyai hubungan makna yang sama, kesan warna hitam jas para pejabat memberi 
kesan kekuasaan, gagah, kuat, dan mewah. Peneliti tidak melihat sisi fungsi dari sebuah jas, tetapi hanya relasi warna dengan kekuasaan yang dimiliki oleh sang penguasa. Jika diamati, warna hitam cenderung dipakai oleh orang memiliki kekuasaan dan kekuatan.

\section{Warna Kayu dan Tambang}

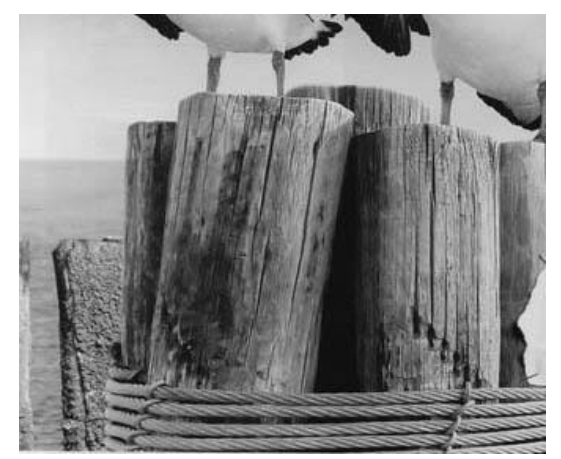

Gambar Kayu dan tambang

Warna kayu Jati dalam iklan berwarna coklat, sedangkan warna tambang yang mengikat kayu tersebut berwarna abu-abu bahan dari kawat baja. Komposisi warna yang natural membuat iklan ini terlihat alami. Komposisi warna coklat pada kayu C: 44 ; M: 46 ; Y: 60 ; K: 13, sedangkan komposisi warna tambang C: $49 ; \mathrm{M}: 38 ; \mathrm{Y}: 47 ; \mathrm{K}: 6$. Makna warna coklat yang berarti nyaman, daya tahan, dan reliable. Makna dalam warna coklat bisa dihubungkan dengan relasi sosial yang saling membantu satu dengan yang lain. Relasi sosial yang memiliki jangka waktu lama, memiliki hubungan yang luas memberikan kesempatan untuk mendapatkan yang harapkan lebih besar, sesuatu yang dapat diandalkan (reliable).

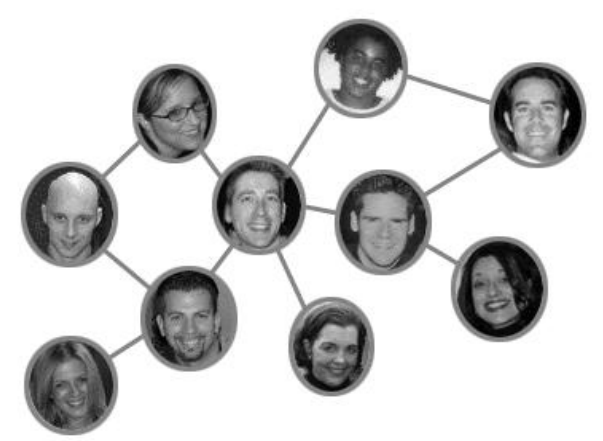

Gambar Relasi Sosial 


\section{Burung Pelikan Tua Berkumpul}

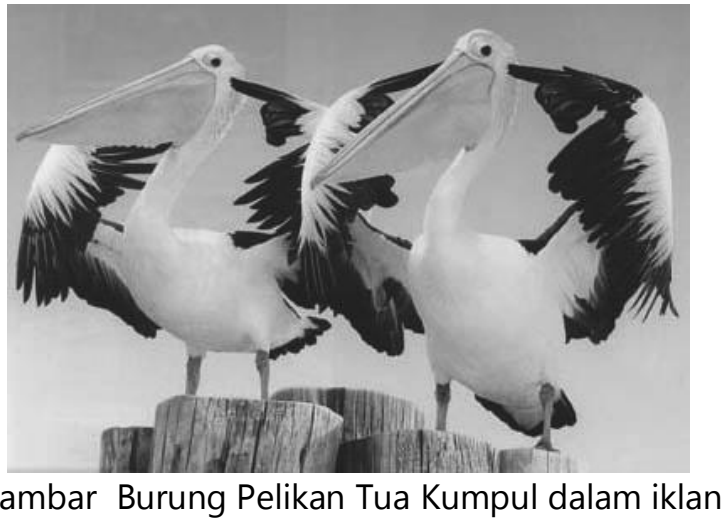

Burung Pelikan merupakan burung yang memiliki paruh besar, burung yang mampu terbang dengan jarak bermil-mil tanpa henti. Paruh yang besar menadi kekuatan baginya untuk bisa memburu makanan seperti ikan-ikan dilaut. Hewan yang suka dengan air ini menjadi burung yang suka dengan makan makanan ikan. Hewan ini suka dengan laut atau sungai untuk mencari makan, kemudian setelah mandapatkan makanannya burung pelikan akan minggir dan berkumpul ditepi laut atau sungai.

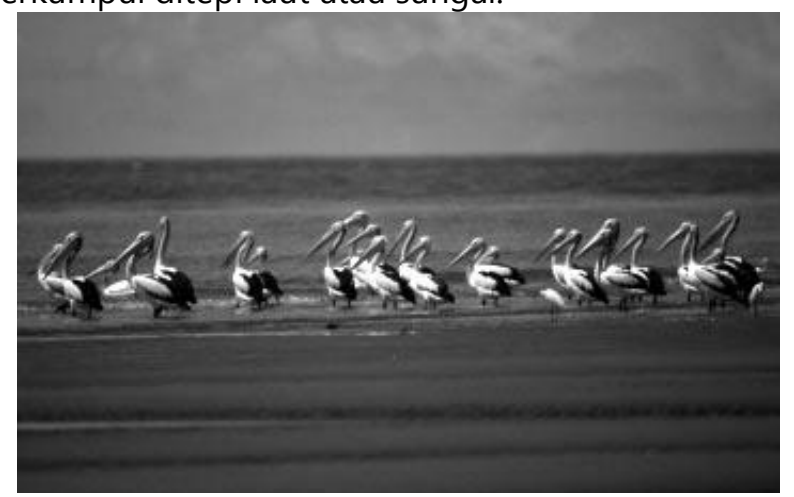

Gambar Burung Pelikan Tua Kumpul dalam realitanya

Aktifitas burung pelikan yang suka bergerombol, merupakan sifat dari burung tersebut untuk melakukan aktifitasnya. Aktifitas yang dilakukan bersama-sama, terkesan burung pelikan ini mempunyai sifat untuk saling kerjasama dan tidak melihat sebuah perbedaan yang bisa memisahkan kekompakan mereka.

Burung Pelikan akan terbang pergi atau pulang untuk bisa mendapatkan makanannya, dan mereka selalu melakukannya secara bersama-sama, mulai dari 
burung pelikan muda hingga yang dewasa atau tua. Burung Pelikan bukan termasuk hewan asli dari Indonesia, tetapi mereka adalah pendatang dari negara Australia. Mereka ke Indonesia hanya mencari makan, setelah mendapatkannya maka gerombolan burung ini akan pergi meninggalkan Indonesia.

Burung Pelikan tua yang ditampilkan dalam iklan A Mild terlihat berkumpul dengan burung pelikan tua lainnya, terkesan memisahkan diri dengan burung pelikan muda. Hal tersebut menjadi sebuah kontradiksi dengan realitas, bahwa burung pelikan didalam kenyataannya tidak memisahkan antara tua dan muda, besar dan kecil, mereka cenderung bergabung untuk melakukan aktifitasnya, mereka lebih menyukai melakukan bersama untuk terbang, berburu, makan dan aktifas lainnya.

Relasi burung pelikan tua yang berkumpul dengan tanda-tanda dalam masyarakat memiliki kesamaan. Masyarakat disini adalah manusia, memiliki prinsip yang suka untuk berkumpul untuk berbicara, nonton bola, diskusi, bekerja, dan lain sebagainya. Aktifitas tersebut tidak jauh berbeda dengan aktifitas burung Pelikan. Sehingga manusia Indonesia memiliki semboyan "makan gak makan asal kumpul", ini menjadi tolak ukur bahwa manusia memiliki kegemaran berkumpul ramai-ramai, karena manusia adalah makhluk sosial, yang tidak bisa hidup sendiri tanpa bantuan dari orang lain.
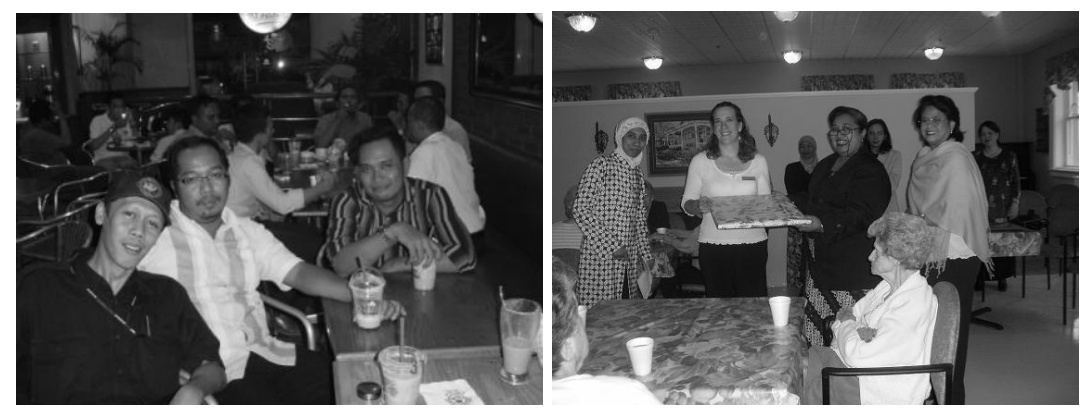

Gambar Aktifitas manusia yang suka kumpul dengan sebayanya.

Relasi tanda pada gambar diatas menjadi sebuah gambaran realitas dimasyarakat. Manusia memiliki prinsip suka berkumpul sama dengan burung pelikan, tetapi diantara prinsip manusia dengan burung pelikan terdapat kontradiksi. Memang benar mereka dalam melakukan aktifitasnya selalu bersama-sama, tetapi dalam diri manusia memiliki paham yang berbeda dengan burung Pelikan. Dalam burung pelikan tidak melihat nilai-nilai pada sesama mereka, burung pelikan tidak melihat nilai relasi sosial, kelas, status, dan strata. Burung pelikan tidak memiliki hal yang dipahami manusia, yang penting dalam diri burung pelikan adalah bisa mencari makan. 
Sedangkan dalam pikiran manusia memiliki nilai-nilai tertentu, yang menjadi sebuah dasar untuk melakukan relasi sosial. Tanpa nilai-nilai seperti kelas, status dan kelas, menusia seperti tidak memiliki etika atau aturan yang mengatur kehidupan sosial menusia. Dalam pemikiran manusia yang telah dipersempit dengan adanya nilai-nilai itu, sehingga terjadi pelapisan-pelapisan sosial yang tebal. Dalam kehidupan sosial manusia, manusia cenderung memilih bergaul dengan orang yang memiliki nilai kehidupan yang sama, memiliki kelas yang sama, status yang sama atau strata yang sama. Pergaulan manusia menjadi suatu hal yang komplek untuk diteliti, tidak seperti pergaulan dalam komunitas burung Pelikan.

Orang tua akan cenderung berkumpul dengan orang sebayanya, orang yang muda akan berkumpul dengan orang sebayanya. Orang miskin akan berkumpul dengan orang yang miskin juga, dan juga pada orang kaya. Hal ini terjadi karena didalam pikiran manusia terdapat etika-etika yang mengatur ini semua. Orang yang miskin akan sulit untuk masuk dan berkumpul dengan orang kaya, anak muda bergabung dengan orang tua. Semuanya harus melalui ujian-ujian etika yang telah disepakati dalam komunitas itu. Nilai - nilai tersebut mempengaruhi manusia untuk berbicara, berpikir, tata krama, "bergaul", dan lain sebagainya, sehingga nilai tersebut menjadi pembatas yang sulit untuk ditembus.

Ada perbedaan jarak antara burung pelikan tua dan muda didalam iklan. Jarak tersebut terlihat jauh dan terpisah beberapa tiang kayu jati dan terlihat lautan yang luas. Nilai yang berbeda dengan kenyataan dalam kehidupan burung pelikan. Kalau dihubungkan dengan kehidupan manusia masih memliki kesamaan kebiasaan. Konsep burung Pelikan yang netral pada figur apapun, mereka tidak memihak pada paham dan nilai tertentu, objek yang terbilang netral untuk dijadikan tokoh dalam iklan. Representasi burung pelikan akan diserahkan pada peneliti atau orang yang melihatnya.

\section{Sayap Burung Pelikan Tua}

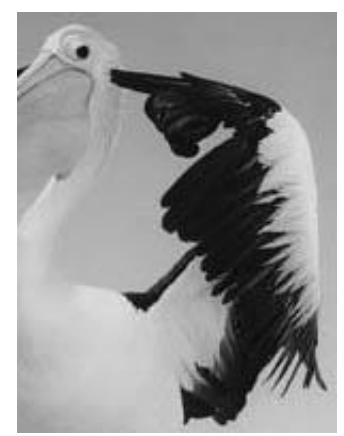

Gambar Sayap burung pelikan 
Burung Pelikan memiliki sayap yang besar dan kuat, dengan sayap yang besar dan kuat ini burung pelikan mampu terbang jauh bermil-mil. Sayap merupakan kekuatan dari burung pelikan. Burung pelikan akan terbang jauh dan lama, mereka bergerombol untuk terbang jauh dengan sayap mereka yang kuat. Sekali gerakan sayap burung pelikan mampu terbang jauh, sehingga burung pelikan kadang disebut sebagai burung penerbang "ulung".

Sayap yang memiliki ciri khas yaitu berwarna hitam dan putih, warna hitam merupakan identitas dari seekor burung Pelikan. Warna hitam semakin besar/ banyak di sayapnya maka burung ini memiliki umur yang banyak dan berpengalaman. Semakin tua seekor burung maka bulu-bulu burung ini akan semakin banyak.

Fungsi dari sayap burung pelikan adalah untuk terbang, mengepak lebar, melindungi dirinya, dan fungsi lainnya. Burung pelikan tidak melakukan gerakan yang bisa dilakukan tangan manusia. Gerakan wajar dari seekor burung pelikan adalah kepakan sayap yang menekuk kebawah, tidak pernah keatas, hal ini karena bentuk konstruksi sayap burung hanya untuk terbang keatas.

Tetapi didalam iklan A Mild, menampilkan gerakan sayap dari burung pelikan tua yaitu menutup lubang telinganya seperti tidak ingin mendengarkan sesuatu dari luar, gerakan sayap burung pelikan tua tersebut mirip seperti gerakan tangan manusia (menutup telinga). Sayap burung pelikan yang lebih mirip tangan manusia, memiliki jari tangan, terlihat sebuah telunjuk yang menutup lubang telinga, dan jari-jari lainnya yang menggenggam erat.

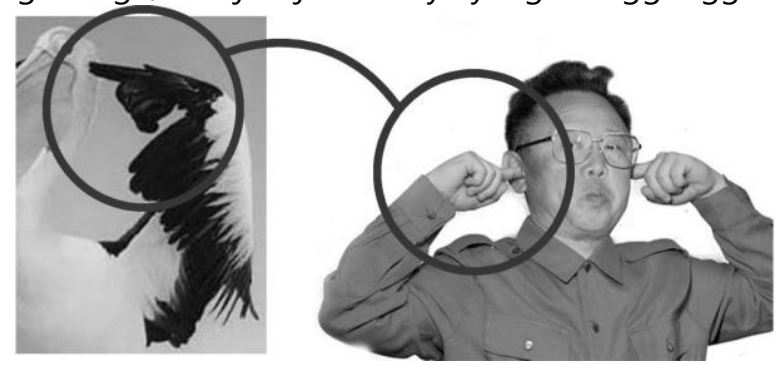

Gambar Relasi tanda pada tangan manusia dengan sayap burung Pelikan dalam Iklan

Referen tanda pada manusia memberikan gambaran bahwa antara gerakan sayap burung pelikan dengan tangan manusia memiliki kesamaan gerakan (seperti bagian yang dilingkari). Padahal kenyataannya burung pelikan tidak mempunyai kemampuan seperti itu, bulu-bulu pada sayap diasosiasikan seperti jubah atau baju yang dipakai oleh manusia, sayap burung pelikan yang berwarna hitam pada ujung-ujungnya memiliki makna yang direpresentasikan oleh peneliti.

Warna hitam adalah simbol sebuah kekuasaan, wibawa, gagah, dan kekuatan. Semakin besar / banyak jumlah warna hitamnya maka semakin 
berkuasa, kuat dan berpengalaman. Sayap yang ibaratkan sebuah "tangan" yang bisa memerintah dengan jarinya, sedangkan warna putih sebagai irama dalam sebuah estetika desain.

\section{Burung Pelikan Tua Melirik}

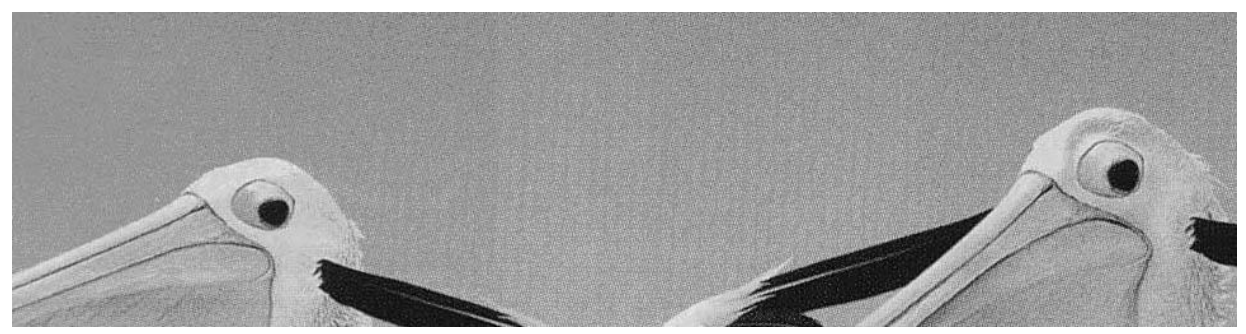

Gambar burung Pelikan melirik

Gambar diatas mengenai burung pelikan yang sedang melirik kekiri, kearah burung pelikan muda. Mata mempunyai isyarat-isyarat yang ingin disampaikan, karena mata memiliki misteri yang tersimpan dari dalam hati. Mata bisa "berbicara" dan melihat, pada saat berbicara dengan lawan bicara, kita pasti melihat kearah mata lawan bicara kita. Dengan melihat mata, kita bisa mengerti makna dan maksud dari inti percakapan itu, karena mata akan menyampaikan isyarat berupa tanda senang, sedih, sinis, marah, malu, lugu, tidak jujur, dan tanda lainnya.

Mata seperti "jendela hati" bagi manusia, dan mata memiliki banyak makna bagi manusia. Arti lirikan pada mata memiliki banyak arti, antara lain melirik untuk melihat, sinis, benci, "menyepelekan", memata-matai, dan menggoda. Tanda dalam iklan A Mild diatas, mata burung Pelikan tua melirik seperti ingin berbicara sesuatu kemudian melirik dengan terkesan "menyepelekan", terlihat pada kelopak yang terbuka lebar dan ada lekukan diatas mata seperti pada lingkaran dibawah ini.

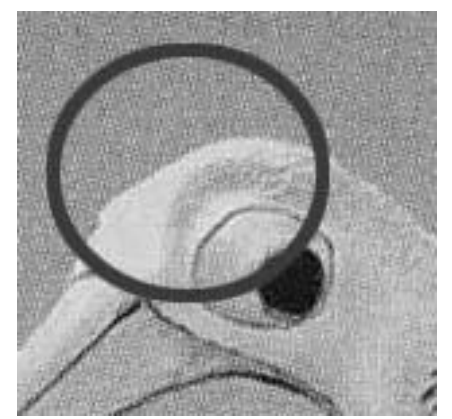

Gambar kelopak mata burung Pelikan tua

Jurnal Ilmu Komunikasi, Vol. 1, No.1, April 2011

ISSN: 2088-981X 
Pada kenyataannya, seekor burung tidak akan bisa melakukan gerakan mata seperti gambar diatas, apalagi melirik seperti manusia. Mata burung hanya bisa bergerak mengikuti arah kepalanya. Tanda seperti ini menimblkan kontradiksi antara kenyataan dengan iklan yang dibuat. Gerakan pada iklan A Mild di relasikan dengan tanda yang ada pada gambar menutup telinga, pada kedua tanda tersebut terdapat kesamaan tampilan, sehingga dapat disimpulkan, bahwa gerakan mata pada burung pelikan tua sama dengan gerakan mata manusia.

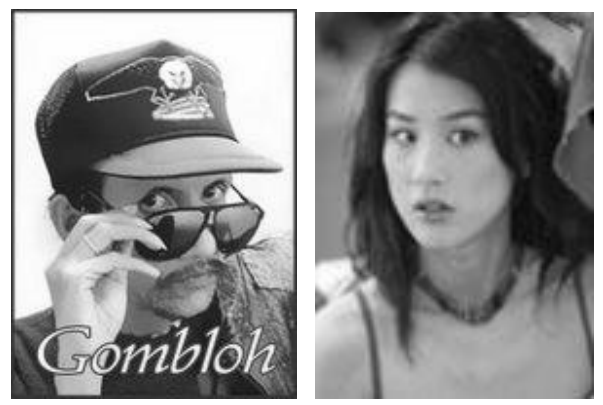

Gambar Mata melirik pada manusia

Satu lirikan yang ada akan melahirkan banyak persepsi yang berbedabeda. Pada gambar burung diatas peneliti merepresentasikan gerakan mata burung pelikan merupakan gambaran tentang sifat yang sinis, dan "Menyepelekan". Relasi tanda mata pada pelikan memiliki kesamaan ciri dengan mata manusia, kesamaan ini dibuat karena mengandung pesan sindiran bagi masyarakat dengan objek yang dialihkan pada objek burung elikan.

\section{Paruh Burung Pelikan Tua dan Pelikan Muda}

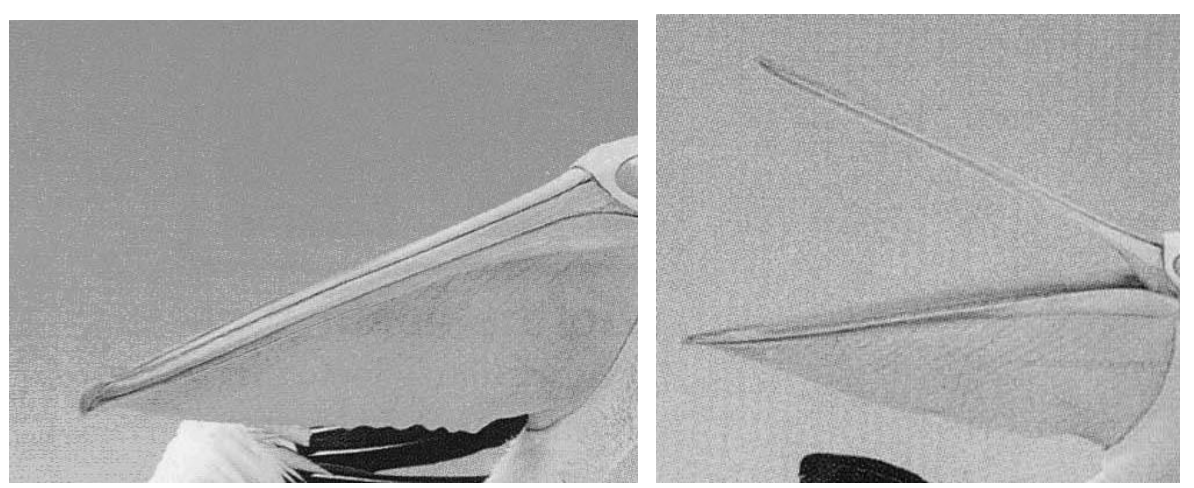

Gambar Paruh burung Pelikan Tua dan Muda

Gambar ini adalah gambar paruh dari burung palikan tua (sebelah kiri) dan burung Pelikan Muda ( sebelah kanan). Paruh adalah mulut dan alat untuk mencari makan bagi seekor burung. Paruh adalah bagian tubuh yang paling 
penting, tanpa paruhnya burung tidak akan bisa hidup normal seperti seekor burung. Paruh adalah ciri utama dari hewan berjenis burung (Aves). Paruh bisa menjadi sebuah senjata bagi burung selain untuk makan dan mencari makanan. Dengan paruh yang kuat maka burung akan semakin kuat untuk berburu atau bertarung.

Paruh bisa digunakan sebagai identitas bagi seekor burung. Paruh yang besar, tebal, kuat dan "berjenggger" (pada jenis tertentu), maka bisa disebut burung ini sudah berumur tua. Sedangkan burung yang muda, memiliki bentuk kecil, kurang kuat, tidak "berjengger". Identitas ini menjadi sebuah tanda bagi peneliti untuk memisahkan antara burung yang tua dengan yang muda.

Paruh kecil dan kurang kuat membuat seekor burung kurang mampu untuk mencari makan sendiri, maka dengan keadaan seperti itu, burung muda akan mengandalkan kemampuan dari induknya atau burung yang sudah memiliki paruh yang kuat.
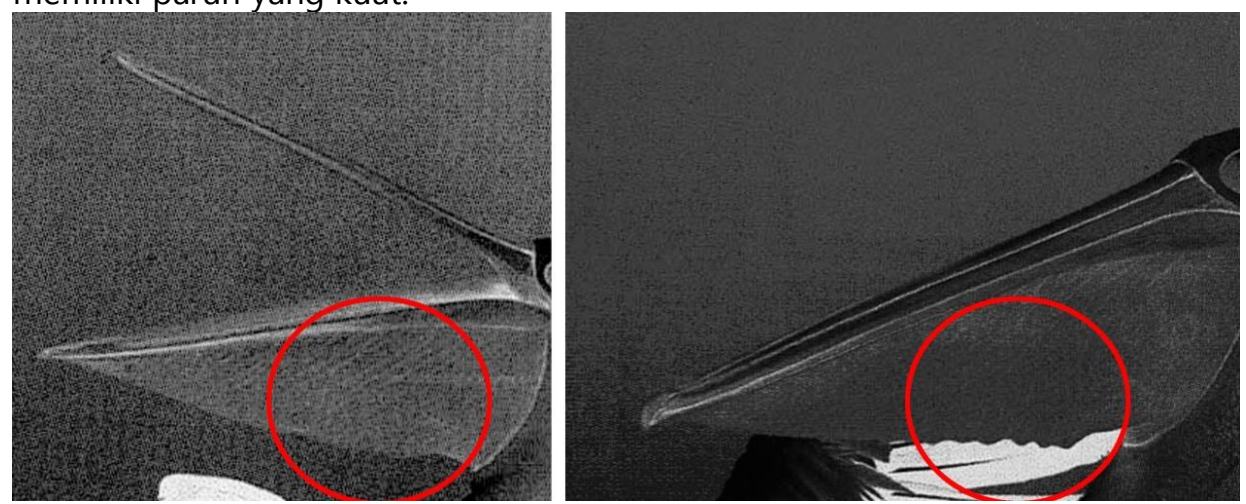

Gambar burung Pelikan Muda (tidak"berjengger") dan Pelikan Tua ("berjengger")

Pada gambar diatas merupakan bentuk "jengger" burung pelikan muda dengan burung Pelikan tua. terdapat perbedaan diantaranya adalah "berjengger" dan tidak "berjengger". Burung pelikan muda terlihat lebih pendek dan lebih kecil daripada burung pelikan tua, warna pada burung pelikan tua lebih matang dan kuat daripada yang muda. Maka referen tanda pada iklan sama seperti pada kenyataannya.

Gerakan pada paruh burung pelikan muda, terlihat seperti ingin berbicara sesuatu pada burung pelikan tua. Mulut terbuka terkesan berbicara atau berteriak dengan lantang, seperti seseorang yang ingin berbicara pada lawan bicaranya. Sedangkan pada burung pelikan tua yang terlihat hanya diam terkesan berwibawa, diam, tenang, berpengalaman, mendengarkan, dan berpikir. Hal ini terlihat pada "mimik" burung Pelikan tua yang hanya tertutup rapat dan tidak sedikitpun terbuka. 
Setting paruh yang terkesan menghadap kekiri (dilihat dari posisi pembaca), mengesankan terdapat sesuatu yang berlawanan atau tdak ada timbal balik. Warna paruh tidak terlihat jelas, sedikit kontras dan saturasi. Sehingga paruh burung pelikan tidak menonjol dalam tampilan visual-nya. Paruh yang ditonjolkan pada bentuk dan ukuran, tidak ada penonjolan pada warna paruhnya.

Dalam referen tanda yang ada dalam paruh dalam direlasikan dengan tanda - tanda dalam kenyataan dengan dihubungkan dengan sosial budaya, ideologi dan relasi sosial, berikut beberapa representasi dari peneliti mengenai paruh:

1. Paruh yang merupakan sebuah kekuatan burung pelikan untuk mencari makan, makan hasil buruannya, melindungi diri, menyuap atau memberi makan anakannya (kalau sudah dewasa). Paruh jika direlasikan dengan kehidupan masyarakat, ibaratkan sebuah kekuatan untuk mencari nafkah bagi dirinya dan keluarga. Paruh untuk mencari makan adalah bagian dari kekuatan ekonomi dari seseorang, ekonomi dilakukan jika mereka sudah mampu melakukan, dan biasanya dilakukan oleh orang dewasa atau tua.

2. Paruh yang besar berarti memiliki tanggung jawab yang besar, paruh ibaratkan umur, semakin oarng yang berumur maka dia akan mendapatkan tanggung jawab yang lebih besar. Selain itu, paruh yang besar ibaratkan pengalaman burung pelikan dalam mencari makanan, berburu dan bertarung

3. Paruh yang "berjengger" dan besar seperti sebuah status seseorang Berjengger ibaratkan wajah manusia yang sudah mulai berjenggot, berkumis dan kulitnya berkerut.

4. Dalam visual iklan ini menggunakan paruh hanya sebagai simbol dari status masyarakat.

5. Paruh ibaratkan mulut yang berbicara, kondisi dalam kenyataannya paruh atau mulut yang terbuka terkesan orang tersebut berbicara. Dalam setting paruh, paruh dalam iklan terlihat saling bertolak belakang, tidak ada hubungan yang harmonis dalam berkomunikasi. Terkesan dingin, karena posisi burung pelikan tua yang membelakangi pelikan muda, terkesan acuh, cuek, mengabaikan, "menyepelekan", padahal ada burung pelikan muda yang mengajak berbicara. Hal ini menjadi sebuah symbol, yang mana terjadi sebuah perbedaan antara tua dan muda, yang tua tidak memberikan hak yang sama pada yang muda, padahal kita saat ini gencar-gencarnya mengusung ideologi demokrasi. Dalam suatu relasi sosial, sulit untuk suatu kelas sosial bisa masuk dalam kelas sosial lain apalagi kelas sosial berada diatasnya, hal ini dikarena tiap kelas sosial memiliki etika-etika yang sudah disepakati bersama dan hanya diketahui oleh kelompoknya sendiri. 


\section{Burung Pelikan Berdiri Diatas Kayu Jati}

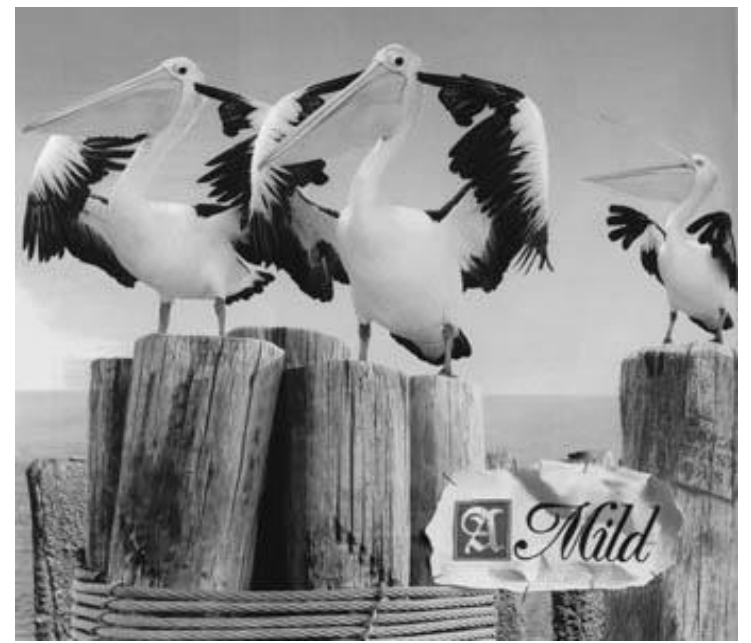

Gambar Setting burung Pelikan Tua dan Muda berdiri diatas kayu Jati

Gambar diatas adalah gambar burung pelikan yang berdiri diatas kayu jati terletak ditepi laut. Burung pelikan yang bukan komunitas asli Indonesia ini menyukai berdiri ditepi laut dengan mencari makan atau sambil berjemur untuk menghangatkan badannya. Burung pelikan yang berdiri diatas kayu dilakukan secara bergerombol sesama burung pelikan, dalam kenyataannya juga seperti apa yang digambarkan dalam iklan. Kebiasaan-kebiasaan yang dilakukan oleh burung pelikan ditampilkan dalam iklan ini, tetapi tidak meninggalkan tandatanda sosial masyarakat dalam relaitasnya.

Dalam setting burung pelikan berdiri diatas kayu jati ini, jika dilihat dari sisi komposisi, maka komposisi burung pelikan tua lebih mendominasi daripada burung pelikan muda, sebagian besar komposisi menampilkan burung pelikan tua, sehingga burung pelikan muda hanya diberi bagian yang berbeda jauh. Untuk posisi tinggi rendah burung pelikan terjadi perbedaan cukup jauh, burung pelikan tua mempunyai posisi yang lebih tinggi daripada burung pelikan muda. Untuk perspektif gambar, burung pelikan tua lebih maju kedepan daripada pelikan muda, sehingga terbentuk aksentuasi objek, dan kemudian menjadi makna yang mendominasi dalam iklan.

Komposisi tidak seimbang juga terlihat pada susunan kayu- kayu, kayu yang dipijak oleh burung pelikan tua berjumlah lebih banyak dan tinggi rendahnya relatif sama. Sedangkan pada burung pelikan muda kayu jati yang dipijak hanya berjumlah satu batang, tetapi memiliki tinggi dan besar yang tidak kalah dengan yang dimiliki oleh burung pelikan tua. 
Kayu jati ditepi laut sering kita lihat, biasanya kayu jati itu berjumlah banyak, dan tersebar di tepi laut, terutama pada tempat-tempat untuk pangkalan kapal atau perahu. Kayu ditepi laut digunakan untuk tempat mengikat tali kapal, sehingga kapal tidak bisa lepas ketengah laut. Kayu-kayu tersebut biasanya dibuat atau dipasang untuk jangka waktu yang lama, kualitas kayu Jati yang kuat pada panas, dingin, basah, kering, tekanan ombak yang kuat, dan hewan-hewan yang merusak, selain itu kayu Jati dipakai karena tidak merusak lingkungan dan tidak menyebabkan polusi air.

Warna kayu coklat muda dengan banyak kerutan-kerutan, maka kayu tersebut bisa mewakili simbol kayu yang sudah tua, sedangkan untuk kayu yang masih muda maka akan terlihat sedikit kerutan. Komposisi kayu dalam iklan pada bagian sebelah kiri, kayu diikat dengan rapi menggunakan tambang, menurut amatan peneliti tambang tersebut terbuat dari baja yang sulit korosi dan kuat. Kayu jati yang biasa digunakan sebagai furniture, kapal, tiang, dan lain sebagainya, merupakan jenis kayu yang mahal, kayu yang biasa dipakai oleh orang yang "berduit", sedangkan orang yang kurang mampu mereka akan membeli kayu dengan harga yang lebih murah.

Peneliti melakukan representasi dengan relasi-relasi referen tanda yang ada dimasyarakat. Representasi peneliti pada burung pelikan tua dan muda berdiri diatas kayu jati.

1. Burung pelikan yang dijadikan objek penelitian, memiliki kesamaan tandatanda konotasi ataupun denotasi. Kalau makna denotasinya, kita bisa melihat makna yang ada sebenarnya tetapi kalau makna konotasi maka peneliti akan melihat makna yang tersirat didalam tanda tersebut.

2. Burung pelikan bersifat "netral", yang dimaksud netral adalah burung pelikan tidak pernah diasosiasikan pada tanda tertentu. Jarang sekali tanda yang menyinggung pada burung pelikan. Berbeda dengan "banteng", kita akan mengasosiasikan dengan partai tertentu, kambing akan mengarah pada suku tertentu, sedangkan burung pelikan tidak mengarah pada apaun.

3. Burung pelikan tidak mengarah pada tanda tertentu dimasyarakat, tetapi didalam iklan, burung pelikan melakukan gerakan, aktifitas, ekspresi yang direlasikan dengan kenyataan manusia. Oleh karena itu burung pelikan dijadikan objek pengganti manusia, karena jika iklan tersebut menggunakan objek manusia, maka ditakutkan akan mempunyai makna yang menyudutkan salah satu golongan Ras atau Suku.

4. Dilihat dari komposisinya, burung pelikan tua memiliki komposisi yang lebih besar atau dominan daripada pelikan muda. Dilihat dari komposisi, maka terlihat kesan kuat dari pelikan tua, segala sesuatu dikontrol oleh orang yang lebih tua, anak muda hanya menunggu perintah, 
mendengarkan, dan patuh pada orang tua. Komposisi tersebut mengesankan adanya budaya Feodal yang membentuk prinsip untuk membatasi hak orang lain, berpikir hirarkis, tidak berpikir kepentingan bersama. Kemudian jika direlasikan dengan ideologi Demokrasi maka akan terjadi hal yang bertentangan. Untuk iklan yang dibuat pada jaman Demokrasi seperti saat ini, maka iklan ini mengkritrik pihak-pihak yang masih berpikir hirarkis, mementingkan kepentingan sendiri dan golongannya.

Selain pada komposisi kanan dan kiri, terlihat pula komposisi tinggi rendah.. Posisi orang tua berada lebih tinggi dan menonjol secara perspektif, sedangkan anak muda lebih rendah dan terlihat lebih jauh. Pesan-pesan melalui tanda seperti ini, memberikan gambaran bahwa relasi sosial dimasyarakat masih terjadi keterpihakan pada kelas tertentu, tidak memihak kebersamaan dan masih melihat perbedaan.

Pada kenyataannya, anak muda tidak seperti orang tua pikirkan, anak muda lebih berpikir maju, cepat, berpikir luas, cerdas, dan memiliki banyak pengalaman, sedangkan pada orang tua tenaganya mulai berkurang, tidak mengikuti perkembangan teknologi, masih berfikir konservatif, dan kurang mengakui orang lain. Tetapi pada kenyataannya, posisi yang diunggulkan adalah posisi orang yang terlihat lebih tua, orang yang lebih diyakini bisa mengatasi masalah sesulit apapun, bijaksana dan berwibawa. Semua hal itu ada benarnya, tetapi apa salahnya jika memberikan kesampatan pada anak muda untuk mencoba, jika memang hasilnya akan lebih baik daripada orang tua .

5. Perbedaan dalam relasi sosial juga terlihat pada pemisahan antara pelikan tua dengan pelikan muda, jarak yang terlihat jauh terpisahkan beberapa tiang kayu jati. Jarak ini melihatkan bahwa pada masyarakat yang berbeda kelas, status atau strata akan sulit untuk bisa masuk dalam masyarakat lainnya yang berbeda kelas, status atau strata dengannya. Sebelum memasuki kelas lainnya, kita harus paham etika yang disepakati didalamnya, inilah ujian yang perlu ditempuh untuk bisa masuk didalam kelompok masyarakat lain. Relasi sosial yang simbolkan dengan rukunnya pelikan tua, yang berdiri bersama-sama dengan kelompok sebayanya. Dengan melakukan gerakan yang sama seperti, terlihat menoleh kekiri, sambil melirik, sama-sama menutup telinga, posisi badan yang membelakangi pelikan muda, jarak yang dekat melihatkan mereka akrab, seperti ada aturan atau etika yang sudah disepakati dalam kelompok pelikan tua. Sedangkan pada pelikan muda dia terlihat berdiri sendiri tanpa seekor teman yang menemaninya, dia merasa kesepian berdiri diatas kayu sendiri, kemudian pelikan muda ingin mengakrabkan diri, menyapa, 
mengajak ngobrol, memberikan solusi, dan saran pada pelikan tua. Tetapi tanggapan pelikan tua terlihat "dingin" dengan membelakangi pelikan muda. Hal ini terjadi karena, pelikan muda tidak mempelajari etika yang sudah ada dikelompok pelikan tua, sehingga dia akan dianggap kurang ajar, tidak sopan, "sok" pintar, tidak masuk akal, "lancang" dihadapan pelikan tua.

6. Kayu jati dan tambang baja ibaratkan posisi antara tempat orang tua dan anak muda. Anak muda terlihat "sempit" dihadapan orang tua, kurang memiliki pengalaman, kurang memiliki koneksi bisnis, sehingga oleh orang tua anak muda dipisahkan dalam pergaulannya kecuali mereka mampu meyakinkan orang tua. Kekuatan, pengalaman, koneksi bisnis, mental dan prinsip orang tua seperti kayu jati yang bergerombol, diikat menjadi satu kesatuan dengan tali tambang yang terbuat dari baja.

\section{Gesture Dan Ekspresi Burung Pelikan Tua dan Muda}

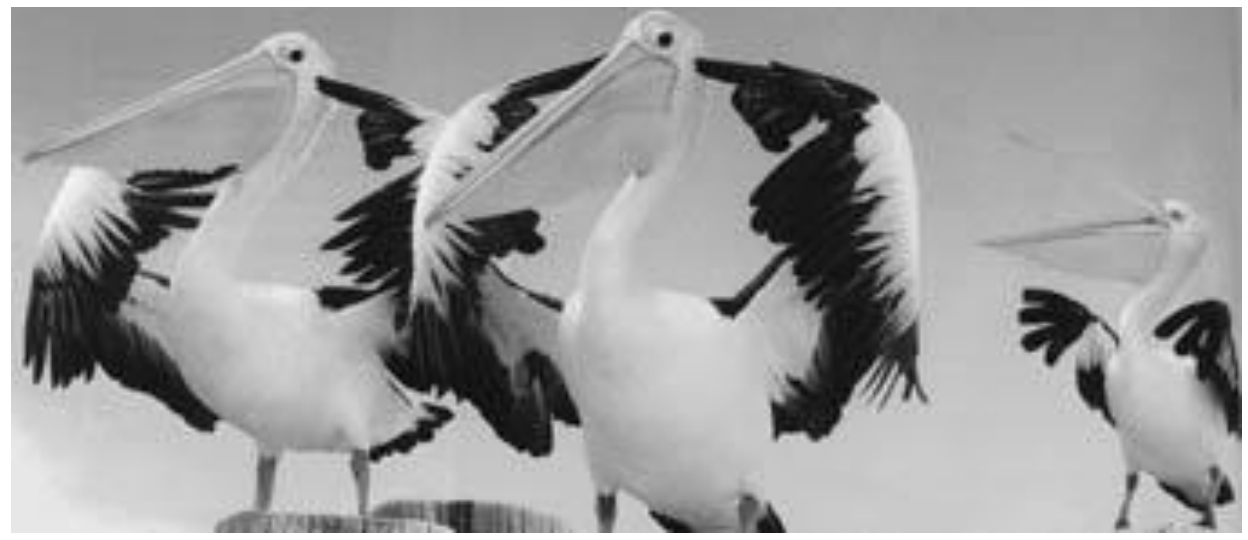

Gambar Gesture burung Pelikan Tua dan Muda

Gerakan dan ekpresi pada burung pelikan ditampilkan pada gambar diatas. burung pelikan merupakan burung yang memiliki sayap yang besar, paruh yang besar, kaki yang pendek dan badan yang besar. Gerak burung pelikan seperti layaknya burung lainnya, yaitu mengepakkan sayap, makan, diam berjemur, dan mencari makan. Burung yang suka makan ikan ini, akan berburu dengan cepat.

Burung pelikan yang suka bergerombol pada saat didarat dan diudara, ada yang besar dan kecil, tidak membedakan diantara mereka. Ekspresi burung pelikan seperti burung lainnya yaitu, diam, dingin, tanpa ekpresi , dan suka berteriak. Hal ini menjadi suatu yang kontradiktif dengan apa yang ditampilkan dalam iklan, iklan A Mild yang menggambarkan burung pelikan bisa seperti apa yang dilakukan oleh manusia seperti menekuk lengannya, melirik, berekspresi, 
sinis, benci, dan lugu. Pada pelikan tua terlihat bisa menekuk sayapnya untuk menuntupi telinganya dengan bulu-bulu yang mirip dengan jari manusia, mata yang melirik, paruh yang turun terlihat seperti menyepelekan pelikan muda. Sedangkan pada pelikan muda terlihat seperti berteriak, berbicara dengan mata yang terkesan seperti anak-anak kecil yang lugu. Gerakan badan yang masih terlihat polos, dan berbicara bebas dengan tidak menghiraukan pelikan lainnya mendengarkan atau tidak.

Burung pelikan tua bergerak terkesan seperti orang yang berkuasa, memimpin didepan, mendominasi tampilan iklan, posisi badan yang tegap berdiri melambangkan dirinya kuat, dan tidak ada tandingannya. Memang dalam kenyataan aktifitas burung pelikan selalu ada pemimpinnya yang paling depan untuk mengarahkan terbang, berjalan dan berburu. Tetapi posisi sebagai pemimpin di kelompok burung pelikan selalu bergantian, yaitu pemimpin akan digantikan oleh pelikan yang berada dibelakangnya, ini terjadi bergiliran. Aktifitas yang mengekor terlihat pada tampilan burung pelikan tua dalam iklan ini, semua burung pelikan tua memiliki gerakan yang sama, semuanya menghadap kekiri, dan mengepakkan sayap. Tetapi bentuk badan yang berbeda menjadikan burung pelikan memiliki perbedaan tanda, yang lebih besar dan depan akan disebut sebagai pemimpin, sedangkan yang lebih kecil dan paling belakang adalah pengawal, pekerja, atau yang paling lemah, sehingga muncul hirarki kelas dan strata sosial.

Gerakan dan ekpresi burung Pelikan dalam iklan berbeda jauh dengan kenyataan yang ada pada burung pelikan, burung pelikan hanya dijadikan sebuah objek utama dalam iklan ini. Tetapi gerakan dan ekspresi yang tampak dalam iklan, yaitu terlihat gerakan dan ekpresi dari manusia. Ekspresi yang sering terlihat dalam kehidupan sehari-hari, seperti melirik, menutup telinga, berbicara, berteriak, diam, menoleh, lugu, marah, heran dan sinis. 


\section{Latar Belakang Lautan dan Langit}

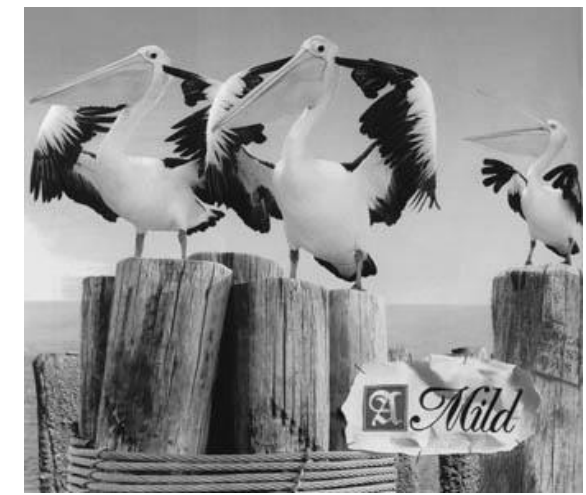

Gambar Latar Belakang Pantai dan Langit

Gambar diatas merupakan gambar mengenai latar belakang lautan dan langit. Di tepi pantai terlihat luasnya lautan dan langit yang berwarna biru dan putih. Warna yang terlihat menakjubkan, warna khas dari sebuah pantai dan langit. Lautan yang terbentang luas terdiri dari air asin yang luas. Lautan yang merupakan sebuah medan "buas" yang sulit ditebak dan ditaklukkan oleh siapapun didunia ini. Banyak korban dan banyak juga yang diuntungkan oleh lautan, kita bisa menikmati menu ikan laut, garam dan makhluk lainnya. Keistimewaan lautan tidak bisa disamakan dengan yang lain, lautan mempunyai ciri khas seperti hasil sumber daya alamnya.

Tetapi dari sisi lain, lautan sangat ditakuti oleh banyak orang. Lautan seperti "neraka", karena jika ditengah lautan maka kita tidak bisa melihat tepian, tidak bisa minta tolong, banyak binatang buas, ombak yang ganas, dan suhu udara yang dingin. Lautan yang tenang akan terlihat menyenangkan, tetapi jika pada saat lautan mulai bergerak atau pasang maka akan terlihat menakutkan bagi yang mendekat. Bagi budaya Jawa, orang yang berimpi laut, dia harus lebih waspada dengan segala kondisi, karena lautan ibaratkan sebuah "cobaan" yang akan menimpanya.

Referen tanda yang ada dilautan merupakan sebuah tanda yang telah direlasikan oleh sebuah kenyataan. Tanda lautan dalam iklan menampilkan lautan yang tenang, tidak ada ombak yang terlihat tinggi, lautan yang terlihat datar dan bersahabat. 

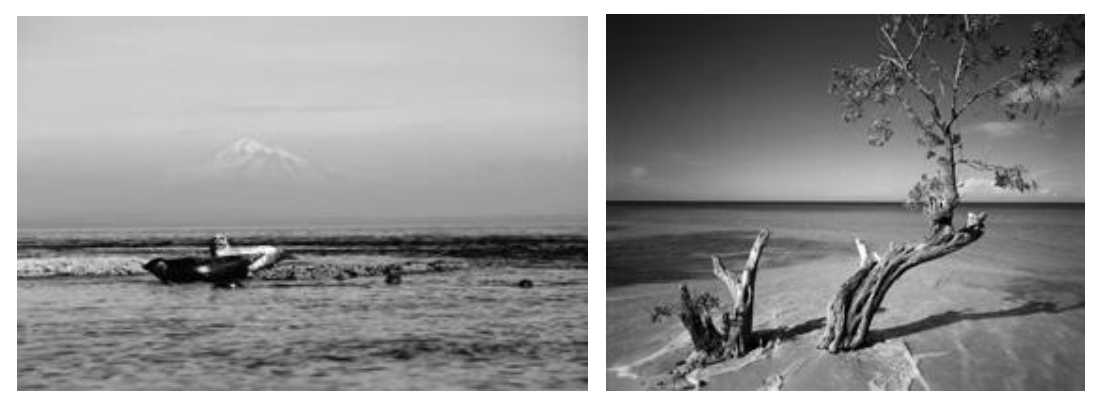

Gambar lautan

Referen tanda diatas terlihat kesamaan antara iklan dengan gambar realitanya. Lautan yang tenang seperti yang terlihat pada gambar diatas.

Sedangkan langit yang ada dalam iklan A Mild, terlihat langit yang bersih, tanpa awan sedikitpun. Langit terlihat terdapat gradasi dari warna putih (bagian bawah) dan biru (bagian atas), komposisi warna yang biru lebih dominan terlihat dalam iklan. Langit ibaratkan sebuah angan-angan yang ingin dicapai, seperti ibarat "capailah cita-citamu setinggi langit", bahwa angan-angan seseorang tidak ada batas yang membendungnya, seberapa kuat-kah anganangan atau cita-cita yang ingin dicapai.

Pada masa anak kecil, kita selalu mempunyai cita-cita yang setinggi langit, cita-cita masa depan yang belum pasti dicapai, tetapi anak-anak sudah bisa membayangkannya. Keinginan harus setinggi mungkin mengarah pada langit, langit dijadikan tempat yang paling tinggi dan jauh. Pada agama Islam langit mempunyai beberapa level, sebanyak 7 tingkatan langit, tingkatan bagi peneliti direpresentasikan sebagai derajat yang ada pada manusia.

Peneliti akan merepresentasikan tanda-tanda dari relasi antara referen tanda dengan kenyataan dalam masyarakat, representasi makna konotasi dan denotasi data diawali dari setting, warna, komposisi, budaya, ideologi, dan relasi sosial. ${ }^{6}$

1. Setting dilautan yang terlihat tenang dan langit yang berwarna biru bergradasi putih. Setting latar belakang yang tidak ramai, menyebabkan penguasaan aksentuasi dapat tertangkap dengan mudah oleh pembaca, latar belakang yang dibuat lebih mengarah pada penekanan aksentuasi burung pelikan, sehingga warna dan setting lautan dan langit tidak dibuat menonjol.

2. lautan yang direlasikan antara referen tanda dengan kenyataan mempunyai persamaan visual, pada segi makna tanda. Lautan mempunyai arti sendiri bagi masyarakat. Lautan diibaratkan sebuah pertanda cobaan yang akan

\footnotetext{
${ }^{6}$ Program Studi Disain Komunikasi Visual FSR ISI Yogyakarta dan Studio Diskom, Irama Visual. Dari Toekang Reklame Sampai Komunikator, (Yogyakarta: Jalasutra, 2007), hal. 35
} 
menimpa kita, biasanya hal ini muncul pada mimpi seseorang. Hal ini merupakan mitos yang ada dimasyarakat tertentu. Jika diasosiasikan dengan tanda lautan dalam keseluruhan iklan, peneliti merepresentasikan bahwa dengan berdiri ditepi atau ditengah laut maka bersiap-siap untuk menantang maut yang akan dating tiba-tiba. Lautan dalam iklan terlihat tenang dan tidak banyak ombak yang menakutkan. Semakin besar ombak yang muncul maka semakin besar cobaan yang akan muncul. Ombak dalam iklan direpresentasikan sebagai bentuk tingkatan cobaan. Ombak yang tenang dan rata mengesankan bahwa burung pelikan tua dan muda telah melewati sagala macam cobaan, sehingga mereka berada pada tingkatan pengalaman, cara berpikir, mental. Semua ini menjadi hal yang mungkin bisa terjadi, antara tua dan muda memiliki kesamaan derajat dalam kehidupan.

3. Warna pada lautan cenderung kearah abu-abu/ silver, warna yang identik dengan warna jaman Millenium, warna tren untuk hal yang bersifat masa depan atau futuristic. Pada tataran warna sebagai tanda, warna memiliki sifat kesepakatan seperti simbol. Lautan bersifat berpandangan jauh kedepan atau untuk masa depan, jika dihubungkan dengan warna abu-abu maka memilki prinsip yang sama. Pada prinsip Feodal yang hidup pada saat ini akan terbentur dengan budaya kebebasan untuk hak masing-masing, hak yang akan didapatkan oleh semua orang menjadi suatu hal yang akan dibawa hingga masa depan, karena pada jaman Demokrasi seperti saat ini, sudah tidak berlaku lagi sifat-sifat Feodal seperti dulu, karena dengan Feodal kita menjadi budak maka akan tetap menjadi budak selamanya. Tidak melihat dia mempunyai pikiran yang cerdas, gagasan yang membangun, ide yang cemerlang, dan kekuatan yang mendukung. Berbeda dengan kita berpaham Demokrasi, hak tiap individu menjadi nomer satu, tidak melihat dia dari pegawai kasar, pekerja terampil hingga pejabat tinggi.

Sedangkan langit adalah suatu angan-angan atau cita-cita yang ada dipikiran kita sejak kecil, langit ibaratkan sebuah tingkatan derajat yang dipercaya oleh agama Islam. Langit adalah sebuah impian yang ingin dicapai. Pada iklan A Mild, terlihat langit yang memilki komposisi warna dari putih ke warna biru, gradasi warna biru menjadi hal yang dominan daripada warna putih. Kemudian peneliti merepresentasi tanda-tanda tersebut, bahwa warna putih adalah bersifat suci, bersih, dan ketidakbersalahan, sedangkan warna biru bersifat kepercayaan, konservatif, keamanan, ideologi, kebersihan dan keteraturan. Perbandingan antara warna biru dengan putih memiliki makna sendiri pada tingkatan derajat seseorang. Terlihat pada burung pelikan tua 
posisi kepala berada lebih tinggi dan mendekati warna biru yang paling atas, sedangkan pelikan muda berada lebih rendah dan masih berada antara posisi warna putih dan biru. Kesimpulannya adalah, pada burung pelikan tua memiliki derajat pemahaman yang berbeda dengan pelikan muda, pelikan tua lebih cenderung memiliki sifat seperti sifat warna biru yaitu kepercayaan, konservatif, keamanan, ideologi, kebersihan dan keteraturan. Sedangkan pada pelikan muda yang masih polos, dia masih memiliki sifat-sifat warna putih. Sehingga meskipun kita akan berada pada posisi yang sama anatar tua dan muda tetapi mereka memilki derajat yang berbeda dan menjadi perdebatan antara tua dan muda, yang tua lebih konservatif, kaku sedangkan yang muda terlihat polos.

\section{Tagline (Tipografi)}

Tagline yang terbentuk dari beberapa rangkaian font sehingga menghasilkan kata yang memiliki arti dan kesan didalamnya. Font ibaratkan sebagai simbol yang memilki makna yang disepakati. Font bisa memberikan kesan formal, nonformal, horror, lucu, tegas, feminism, macho, dan lain sebagainya. Hal ini menunjukkan demikian banyaknya jenis dan karakter huruf yang bisa digunakan dalam desain iklan. Sebab beberapa jenis huruf bisa menciptakan kesan-kesan tertentu sesuai dengan tema iklan ${ }^{7}$. Font memiliki kesan dan mengikuti tema dari iklan, Tagline iklan A Mild yang memiliki jenis font Blok yang berkarakter gemuk dan terkesan berat, yang sering digunakan sebagai headline. Setiap jenis font memiliki makna tersendiri yang ingin disampaikan, dengan melihat font, pembaca iklan bisa menangkap kesan, tujuan, makna apa yang ada dibalik iklan itu.

Pemilihan bentuk Font blok yang terlihat tebal dan tegas, bahwa pembuat iklan memberikan penegasan pada makna yang ada dalam iklan tersebut. Makna yang dibentuk untuk mengkritik budaya masyarakat saat ini. Penegasan terlihat pada dominasi font yang tebal. Tetapi dibuat tidak terkesan formal sehingga iklan ini menjadi sebuah hiburan yang bersifat komersial dan mengkritik. Kesan yang jauh dari formal terlihat pada pemilihan tema dan font, karena produk yang dikomersialkan adalah produk mayoritas untuk anak muda.

\section{Kesimpulan}

Kondisi yang digambarkan dalam iklan ini menjadi sebuah hal yang menarik dan menghibur. Iklan merupakan salah satu media untuk memberikan informasi dan hiburan bagi masyarakat. Iklan A Mild mempunyai nilai estetika yang menarik, mulai dari pemilihan objeknya, warna, latar belakang, komposisi dan tema yang jarang ditemui di iklan lainnya. Tanda yang ada di dalam iklan A 
Mild tidak seperti tanda yang ada di iklan rokok lainnya, iklan A Mild terlihat bermain tanda yang sangat berhubungan dengan fenomena masyarakat, sehingga A Mild tidak hanya sebagai iklan komersial tetapi A Mild juga sebagai iklan Layanan Masyarakat.

Kajian ini mengarah pada sebuah kritikan masyarakat melalui media iklan. Dalam kajian penelitian ini peneliti merepresentasikan budaya Feodal dalam Iklan A Mild tersebut. Iklan bagi peneliti merupakan sebuah objek penelitian yang menarik, karena bisa sebagai alat promosi, hiburan, dan informasi. Dalam iklan A Mild ini, tampilan iklan memiliki keunikan dalam makna dan visual, karena bentuk objek dari iklan Mild tidak pernah ditampilkan sebelumnya, yaitu burung pelikan. Burung dari Australia ini memiliki gesture yang unik, dibentuk untuk mewakili kritikan pada masyarakat, figur burung pelikan yang "netral", tidak mengesankan pada lapisan atau golongan masyarakat tertentu..

Budaya Feodal pertama kali muncul secara subjektif dari peneliti, peneliti melihat adanya nilai budaya Feodal dalam iklan pada posisi burung pelikan tua dan muda, posisi yang memperlihatkan terdapat perbedaan dalam relasi sosial, burung pelikan muda terlihat lebih kecil sedangkan pelikan tua terlihat lebih dominan, mendekat dan menjadi aksentuasi dari iklan. Selain itu pada komposisi yang ada, pelikan tua mendominasi sebagian besar komposisi dari iklan ini. Ketidakseimbangan dari komposisi dan posisi burung sudah terlihat jelas bahwa terdapat perbedaan dalam relasi sosial.

Perbedaan tersebut semakin diperkuat dengan adanya tampilan burung pelikan tua dan muda yang tidak terlihat harmonis, terlihat kritikan yang dibentuk untuk masa demokrasi saat ini, yang mana masyarakat sedang berjuang untuk menyuarakan kebebasan berpendapat, dan menerima perbedaan, tetapi dalam praktek dan kenyataannya berbeda. Maka dengan adanya figur pelikan ini, banyak lapisan masyarakat yang dikritik. Demokrasi yang dibangun harus bisa menerima pendapat yang membangun, tidak melihat kelas, status, dan strata seseorang. Karena pada prinsipnya setiap orang memiliki asal dan tujuan yang sama .

Dengan prinsip seperti itu, budaya-budaya yang ada dimasyarakat tidak dijadikan sebuah perbedaan. Karena tiap perbedaan akan menimbulkan perpecahan horizontal, dan tidak akan menguntungkan kedua belah pihak. Budaya Feodal dalam iklan A Mild menjadi sebuah wacana untuk introspeksi pada kita semuanya, bahwa sudah saatnya tidak melihat perbedaan pada relasi sosial, sudah saatnya melihat kedepan bersama tanpa memandang rendah satu sama lain.

Tampilan iklan yang mengarah pada budaya Feodal dimasyarakat, terlihat jelas dalam tampilan iklan. 
1. Tampilan burung pelikan yang terlihat memisahkan diri antara tua dan muda.

2. Ekspresi burung pelikan tua yang tidak menyambut dengan baik pendapat darai pelikan muda. Hal ini dikarena adanya perbedaan nilai sosial.

3. Gerakan tubuh burung pelikan tua yang tidak mau mendengar, sinis, menyepelekan dan "cuek" dari pelikan muda.

4. Tagline "Belum Tua Belum Boleh Bicara", ini menandakan suatu gerakan untuk membatasi hak mengutarakan pendapat. Sehingga terjadi pertentangan dengan Demokrasi, yang memberikan kebebasan berpendapat. Apa anak muda harus menunggu menjadi tua dulu untuk bisa berpendapat dan diterima oleh orang lain, ini sebuah fenomena di masyarakat yang harus dihilangkan, karena akan membuat lapisan masyarakat lebih tebal, dan menghambat perkembangan bangsa menjadi bangsa yang lebih maju.

5. Komposisi burung pelikan tua dan muda yang tidak seimbang, sehingga terkesan terdapat dominasi tanda pada burung pelikan tua. Komposisi bagi peneliti dilihat sebagai hirarki sosial.

Tampilan diatas dilihat secara subjektif oleh peneliti, bahwa terdapat nilainilai budaya masyarakat yaitu Feodal. Yang terlihat pada tanda seperti komposisi, gesture, warna, dan ekspresi. Tanda yang dihubungkan dengan pengalaman seseorang melihat tanda, sehingga setiap orang memiliki makna yang berbeda -beda, tergantung dari persepsi orang yang melihat. 


\section{Daftar Pustaka}

Bungin, Burhan 2006. Sosiologi Komunikasi. Teori, Paradigma, dan diskursus teknologi Komunikasi dimasyarakat. Kencana, Jakarta

Greetz, Clifford 1992. Kebudayaan dan Agama. Kanisius, Yogyakarta

Drs. Sobur, Alex, Msi 2003, Semiotika Komunikasi, PT. Remaja RosdaKarya, Bandung

Fiske, John 2006. Cultural and Communication Studies. Jalasutra, Yogyakarta

Herusatoto, Budiono 2001, Simbolisme dalam Budaya Jawa. Hanindita Graha Widya, Yogyakarta..

Horton. Paul. B. Hunt. Chester. L 1984. Sosiologi. Edk 6 . Jilid 1. Penerbit Erlangga, Jakarta

Jefkins, Frank 1997. Periklanan, edk 3. Penerbit Erlangga, Jakarta

Johannesen, Richard, L 1996. Etika Komunikasi, PT. Remaja Rosdakarya, Bandung

Koentjaraningrat 2004, Kebudayaan, Mentalitet, dan Pembangunan. Gramedia, Jakarta

Maran, Rafael, Raga 2001 Pengantar Sosiologi Politik . PT. Rineka Cipta Jakarta

Mcquail, Denis 1987. Teori Komunikasi Massa. Edk 2. Penerbit Erlangga Jakarta

Noth, Winfried 2006. Semiotik, Airlangga University Press, Surabaya

Pemuka Pasar Indonesia 2006. Strategi Komunikasi Empat Merek Lokal. PT. Duta Cakrawala Komunika. Nopember.

Program Studi Disain Komunikasi Visual FSR ISI Yogyakarta dan Studio Diskom. 2007. Irama Visual. Dari Toekang Reklame Sampai Komunikator Visual. Jalasutra. Yogyakarta.

Sills L, David 200. International Encyclopediaof The Social Sciences, Vol 5 dan 6 Complete and Unabridged.

Sutrisno, Mudji 2005, Cultural Studies. Tantangan Bagi Teori-teori Besar Kebudayaan. Koekoesan, Depok.

Sutrino, Mudji, \& Hendar, Putranto 2005. Teori- teori Kebudayaan, Kanisius, Jakarta

Sujarwa, Drs 1999. Manusia dan Fenomena Budaya, menuju Perspektif Moralitas Agama. Universitas Ahmad Dahlan, Yogyakarta. 
Stokes, Jane 2007. How To Do Media and Cultural Studies. Panduan untuk Melaksanakan Penelitian dalam Kajian Media dan Budaya. Bentang, Yogyakarta.

Tankard, James W, Jr. Severin Werner J 2001. Teori Komunikasi. Sejarah, Metode , dan Terapan didalam Media Massa. Edk 5. Prenada Media, Jakarta

Thomas, Linda, Wareing, Shan 2007. Bahasa, Masyarakat, \& Kekuasaan. Pustaka Pelajar, Yogyakarta.

Weber, Max 2006. Sosiologi. Pustaka Pelajar. Yogyakrta.

Widyatama, Rendra 2007. Pengantar Periklanan. Pustaka Book Publisher, Yogyakarta.

Worsley, Peter, et.el 1992. Pengantar Sosiologi. Sebuah Pembanding. Jilid 2. PT. Tiara Wacana. Vb, Yogya. 